\title{
Organization and Running of the National Plebiscite for Peace in Opole Voivodeship*
}

\section{ADRIANA DAWID}

University of Opole

(iD) https://orcid.org/0000-0002-5098-5974

\section{ROCZNIK}

\section{ZIEM}

\section{ZACHODNICH}

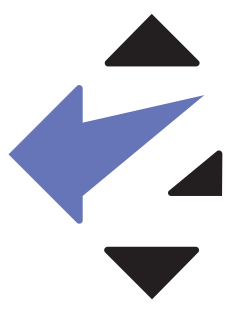




\section{Introduction. Main initiatives of Peace Defenders Movement (1948-1951)}

In a tense political atmosphere, when soon after the end of the Second World War the threat of the outbreak of another military conflict was growing, the international Peace Defenders Movement became active. This movement, inspired by the extreme Left, was an element of the ideological and political campaign of the day conducted by the USSR, its allies and international structures of communist party (Cominform). The activities of the peace defenders generated a vivid social response. The effects of the increasingly distinctly visible bi-polar division of the world and the possible use of new types of weapon, mainly of nuclear character, were widely feared. Between 25 and 28 August 1948, the World Congress of Intellectuals in Defence of Peace took place in Wrocław - the first important organisational meeting of pacifists. Soon thereafter, in April 1949, the First World Congress of Defenders of Peace was held simultaneously in Paris and Prague with the participation of 2,000 delegates from 72 countries. During the Congress, a World Committee of Partisans for Peace was established, chaired by professor Frederik Joliot-Curie, associated with the French communist party. Poland was the host of another World Congress on 16 to 22 November 1950. Over 2,000 delegates from 81 countries condemned American intervention in Korea, remilitarisation of Western Germany and Japan as well as the arms race. The congress in Warsaw saw the creation of the World Peace Council that was to direct the movement of defenders of peace from then on (it assumed the responsibility of World Committee of Partisans for Peace). Joliot-Curie, mentioned above, became its chairman. The community of defenders of peace came to be an essential element of a political and ideological struggle - it was the instrument of the Soviet bloc for influencing the political climate in Western countries, governments of states belonging to NATO. The movement gained wide, transnational range. It gathered representatives from different backgrounds and political groups, many Churches and denominations. Thus, it had a significant impact on shaping public awareness. Politically and financially dependent on Moscow leadership, it became an important weapon of the then created "anti-imperialistic front".

Apart from organising national and international congresses, meetings and conferences, the Peace Defenders Movement arranged numerous mass meetings and demonstrations. Initiatives of international character were an important part of its activity. In the early period of the movement's activity, two campaigns for collecting signatures under peace appeals were organised. These were to include hundreds of millions of people in tens of countries. The first of these campaigns was connected with The Appeal on the prohibition of the nuclear weapons that was announced by the World Committee during its debates in Stockholm in March 1950. Ultimately, the appeal was signed by about 500 million people around the world. In less than a year, in March 1951, the World Peace Council in Berlin announced an appeal to conclude

\footnotetext{
* This paper is a translation of the Author's paper Organizacja i przebieg Narodowego Plebiscytu Pokoju w województwie opolskim, published in this Issue of "Yearbook of the Polish Western Territories" on pages 246-279.

1 For more about the movement of the Peace Defenders Movement, see: J. Ślusarczyk, Ruch obrońców pokoju 1948-1989. Kompendium, Warszawa 1996.
} 
a Peace Treaty among the world powers. Another similar initiative was taken in 1955, when the so-called Vienna Appeal was proclaimed against preparations for nuclear war (about 700 million people signed the appeal). Subsequently, similar appeals do not appear until the $1970 \mathrm{~s}^{2}$.

In Poland, organisational structures of the peace defenders movement began to develop in 1949. In March of that year, the Polish Committee of the Defenders of Peace (PKOP - Polish abbreviation) came into being, chaired by the Marshall of the Legislative Sejm of the Polish Republic, Professor Jan Dembowski. This movement created a complex network of Committees of the Defenders of Peace (KOP in Polish) from central level through voivodeships, poviats, and municipalities to gromady, company or estate level ${ }^{3}$. From the beginning of its activity, PKOP was involved in initiatives of the movement of the defenders of peace and supported its ideological message. It actively participated in activities and decisions of the World Committee and then the World Peace Council. In the early 1950s PKOP, among other things, actively supported a campaign condemning the intervention of the United States in Korea, and organized assistance for its citizens "fighting for unity of the country". In 1950, PKOP joined the campaign to collect signatures as part of the Stockholm Appeal - officially this initiative gained absolute support in Poland because - as it was announced - the appeal had been signed by almost all the country's adult citizens. In less than a year, PKOP faced the task of again mobilizing Polish citizens to sign a new peace address, the so-called Berlin Appeal. This new peace initiative was proclaimed by the World Peace Council in February 1951. It was de facto an appeal for concluding a Peace Treaty between the USSR, the United States, China, Great Britain and France, as proposed by the USSR in 1949. According to the World Peace Council, any state could join the treaty later. The proposition of The World Peace Council Appeal for concluding the Peace Treaty among five great world powers met with massive, though organised and controlled by communist parties, support. In accordance with an official announcement of the World Peace Council, 650 million people signed the appeal worldwide. The call for concluding the Peace Treaty was conveyed to the governments of the five great world powers in March 1953. The campaign to collect signatures did not bring a measurable result, that is - the conclusion of a Peace Treaty. Its success was mainly propaganda in character - it clearly presented the USSR and its allies as the initiators of peace activities and states of the competing Western bloc as imperialistic warmongers. In Poland PKOP, at its plenary meeting held on 31 March 1951, passed the Manifesto to the Polish Nation, calling for the Berlin Appeal to be signed. This new campaign was delivered in a slightly modified form - it was announced as the National Plebiscite for Peace that was to last several days beginning from 17 May. As in the case of the Stockholm Appeal, it officially gained full social support, collecting about 18 million signatures representing almost all adult Poles ${ }^{4}$. 
This text aims at characterising the running of the National Plebiscite for Peace in Opole Voivodeship. These events have not been thoroughly elaborated so far and will be recreated on the basis of archive documents and press reports. Materials from field committees of the Polish United Workers' Party (PZPR in Polish) from the Central Archives of Modern Records in Warsaw and the State Archives in Opole turned out to be most valuable in this respect. The documents of the Voivodeship Committee of the Defenders of Peace (WKOP in Polish) in Opole unfortunately are only fragmentary. Searches conducted in the Archives of the Institute of National Remembrance and the Diocesan Archives in Opole were not as fruitful as it had been assumed. Press reports published among others in "Trybuna Robotnicza" ("Workers' Tribune") and "Dziennik Zachodni" ("Western Daily") complement the source database ${ }^{5}$.

\section{Preparations for the National Plebiscite for Peace}

The first clear response in Opole Voivodeship to the proclaimed plebiscite was a fivethousand-strong rally organised in Opole at the beginning of April, during which a resolution supporting PKOP manifesto was adopted. The message content was to prove that Opole inhabitants had accepted the idea of the plebiscite and shared the authorities' opinion on threat to peace from the West. The resolution said among others that: "Together with the whole people of the world, with millions of peace defenders, led by the powerful Soviet Union, we are ready to do all we can so that murderers driven by the dollar would not be able to realise their crazy plans of sinking people in a sea of blood and tears" ${ }^{\prime \prime}$.

PKOP was responsible for the organisation of the plebiscite planned for 17 May. It engaged its field departments in this campaign. Leonard Sylwester was the chairman of WKOP in Opole and Czesław Lewicki was the secretary. The head office of the voivodeship KOP management was located at 16 Reymont Street. The Committees of the Defenders of Peace worked irregularly and were only mobilised for different campaigns - the last one before the plebiscite had been about collecting gifts for Korean children and had ended at the beginning of the year. Therefore, these structures needed a certain reorganisation and in some cases activation. On 16 April in Opole, an extended plenary meeting of WKOP took place, during which a PKOP delegate from Warsaw presented a paper on the resolution of the World Peace council session in Berlin, and the resulting tasks for the movement. Until the end of April similar meetings, during which the plans of work before the plebiscite were discussed, occurred at poviat levels, and at the beginning of May in municipal peace committees? ${ }^{7}$ The briefing for poviat KOP

5 The titles of newspaper magazines as well as the titles of individual press articles given in footnotes and all citations appearing in this text were translated into English by the translator of the text (translator's note) 
chairmen and WKOP plenipotentiaries was planned for $10 \mathrm{May}^{8}$. In the course of the campaign before the National Plebiscite for Peace, many new peace committees were established. They appeared at places of work, cooperatives, state agricultural farms, gromady and schools. In cities they were formed for particular districts, even streets or blocks. By 10 May, as many as 2,790 KOPs, including 949 work places and 562 schools, were active. The organisational increase in committees did not progress steadily in the initial phase of preparations, it developed the least in the poviats of Brzeg and Prudnik ${ }^{9}$. Later on, city committees in Opole, Olesno and Prudnik began to be established ${ }^{10}$. The dynamics of the increase in the number of committees was high - during the plebiscite 3,415 units were active and they gathered 19,413 members ${ }^{11}$. People already recognised for their social commitment were incorporated into committees. For example, they had participated in the campaign to collect signatures as part of the Stockholm Appeal or help for Korea ${ }^{12}$. According to top-down guidance, the composition of committees was not coincidental - special effort was made so that in

8 Cała Opolszczyzna dokumentuje swq wolę walki o pokój i Plan 6-letni (The Entire Opole Region Documents its Struggle for Peace and the Six-Year Plan), “Trybuna Robotnicza”, 12 May 1951.

9 Opolszczyzna w pełni przygotowana do należytego przeprowadzenia Plebiscytu Pokoju (Opole Region Fully Prepared for Proper Conducting of the National Plebiscite for Peace), "Dziennik Zachodni", 10 May 1951; 20674 agitatorów przeszkolono na Opolszczyźnie (20,674 Agitators Were Trained in Opole Region), “Trybuna Robotnicza”, 9 May 1951.

10 Street committees were also, though reluctantly, formed. These were established only after an explicit intervention from the PKOP plenipotentiary from Warsaw. AAN, KC PZPR w Warszawie, sygn. 237/VII-234, Sprawozdanie z wyjazdu służbowego do woj. opolskiego z 28 V 1951 r. (Report on the official trip to Opole Voivodeship from 28 May 1951), card 37.

11 Archiwum Państwowe w Opolu (The State Archives in Opole; further: APO), WKOP, sygn. 1, Sprawozdanie z działalności politycznej i organizacyjnej Woj. Komitetu Obrońców Pokoju w Opolu i terenowych Komitetów Obrońców Pokoju za 1951 r (Report on political and organisational activity of the Voivodeship Committee of the Defenders of Peace in Opole and field Committees of the Defenders of Peace for the year 1951), unnumbered pages (this report is in APO too, Komitet Wojewódzki (the Voivodeship Committee; further: KW) PZPR w Opolu, sygn. 256, cards 273-281). See: APO, KW PZPR w Opolu, sygn. 1733, Ocena kampanii Narodowego Plebiscytu Pokoju przez Egzekutywe KW PZPR Opole [25.05.1951 r.] (Evaluation of the National Plebiscite for Peace campaign by KW PZPR Executive in Opole [25.05.1951]), unnumbered pages. On KOPs number increase dynamics, see: AAN, KC PZPR, sygn. 237/VII-1696, Wewnętrzny Biuletyn Informacyjny Referatu Sprawozdawczego KW PZPR w Opolu z 14 V 1951r. (Internal News Bulletin of Reporting Department in Opole from 14 May 1951); APO, KW PZPR w Opolu, sygn. 248, Informacja Wojewódzkiego Komitetu Obrońców Pokoju z przygotowań do Narodowego plebiscytu Pokoju z 3 V 1951 r (Information from the Voivodeship Committee of the Defenders of Peace preparations to the National Plebiscite for Peace from 3 May 1951), card 30; ibidem, sygn. 248, card 77, Informacja w sprawie przebiegu kampanii plebiscytowej z 18 V 1951 r. (Information on the plebiscite campaign running from 18.05.1951); 2790 Komitetów Obrońców Pokoju pracuje na terenie woj. Opolskiego (2,790 Committees of the Defenders of Peace Work in the Territory of Opole Voivodeship), “Trybuna Robotnicza”, 13.05.1951; 20 674 agitatorów... The fast pace of establishing committees may be illustrated by an example from Grodków Poviat, where before the plebiscite there were 26 committees but by 10 May 194 committees had been organized. APO, Komitet Powiatowy (Poviat Committee; further: KP) PZPR w Grodkowie, sygn. 43/VI/6, Sprawozdanie opisowe Powiatowego Komitetu z organizacji i przebiegu Narodowego Plebiscytu Pokoju na terenie powiatu grodkowskiego [1951 r.] (Descriptive report by Poviat Committee on the organisation and running of the National Plebiscite for Peace within the jurisdiction of Grodków Poviat [1951]), unnumbered pages. In Opole the number of city committees increased at that time from 128 to 170. APO, Komitet Miejski (City Committee; further: KM) PZPR w Opolu, sygn. 50/IV/3, Protokół z posiedzenia Egzekutywy KM PZPR w Opolu z 15 V 1951 r.(Minutes from KM PZPR Executive meeting in Opole from 15.05.1951), cards 164-166.

12 For example APO, KP PZPR w Raciborzu, sygn. 53/II/1, Sprawozdanie przebiegu plebiscytu narodowego na terenie Raciborza (Report of the national plebiscite running in the territory of Racibórz), unnumbered pages. 
every committee there was representation of women, young people, clergymen, independents and those belonging to PZPR. Due to the specificity of the region, attention was paid that autochthones would be members of the committees. In Opole Voivodeship, apart from a few exceptions, committees taking such diversity into consideration were successfully established. As for autochthones from some poviats, it was reported that their representatives constituted 70 percent of committee members ${ }^{13}$. KOP members were excused from their official duties at work for the duration of the plebiscite campaign. In cases when a committee turned out to be inefficient, auxiliary youth sections were organised - ultimately, 532 of these were established ${ }^{14}$. On 30 April the Voivodeship Commission of Intellectuals and Catholic Activists, which cooperated with PKOP, organised a conference in Opole with the participation of delegates from the majority of poviats. During debates chaired by Reverend Professor Michał Banach, those gathered discussed the participation of clergymen and secular activists in the plebiscite, and appealed to everybody for active engagement in the preparations ${ }^{15}$.

WKOP appointed plenipotentiaries for particular poviats to control preparations. The whole campaign was monitored by report-evidence sections working alongside voivodeship and poviat committees. The running of the plebiscite in Opole Voivodeship was overseen by three plenipotentiaries from Warsaw, representatives of $\mathrm{PKOP}^{16}$. At poviat KOP level, plenipotentiaries for individual municipalities and intermediaries for contacting mass organisations were appointed ${ }^{17}$.

13 AAN, KC PZPR w Warszawie, sygn. 237/VII-234, Sprawozdanie z wyjazdu służbowego do woj. opolskiego z 28 V 1951 r (Report on official trip to Opole Voivodeship from 28.05.1951), card 38. Committees in Walce, Biedrzychowice, Gostomia, Kornica, Głogówek and Biała Prudnicka were to be totally dominated by autochthones. Tysiqce mieszkańców Opolszczyzny biorq udział w przygotowaniach do Plebiscytu Pokoju (Thousands of Opole Region Inhabitants Take Part in Preparations to the Plebiscite for Peace), "Trybuna Robotnicza", 15.05.1951. In Namysłów Poviat, women constituted 60 percent of committee staff. Cała Opolszczyzna dokumentuje swa wolę walki o pokój i Plan 6-letni (The Entire Opole Region is Documenting its Fight for Peace and the Six-Year Plan), "Trybuna robotnicza", 12.05.1951. According to some reports it was as much as 90 per cent of the population. See for example: Tysiqce mieszkańców Opolszczyzny biorq udział w przygotowaniach do Plebiscytu Pokoju (Thousands of Opole Region Inhabitants Take Part in Preparations for the Plebiscite for Peace), "Trybuna robotnicza", 15.05.1951.

1411.313 młodzieżowych agitatorów na Opolszczyźnie wyruszyło $w$ teren aby głosić hasła pokoju $(11,313$ Youth Agitators in Opole Region Went out into the Field to Preach Peace Slogans), "Trybuna Robotnicza", 14 May 1951; Cała Opolszczyzna dokumentuje swa wole walki o pokój i Plan 6-letni (The Entire Opole Region is Documenting its fight for peace and the Six-Year Plan), "Trybuna Robotnicza", 12.05.1951.

15 AAN, KC PZPR w Warszawie, sygn. 237/VII-2659, Biuletyn Informacyjny Komitetu Wykonawczego Polskiego Komitetu Obrońców Pokoju nr 1 z 4.05.1951 (News Bulletin of Polish Commitee of the Defenders of Peace Executive Committee no. 1 from 4.05.1951), card 99. Inteligencja i działacze katoliccy Opolszczyzny włączajq się do akcji Narodowego Plebiscytu Pokoju (Intelligentsia and Catholic Activists of Opole Region Join the Campaign of the National Plebiscite for Peace), "Dziennik Zachodni", 5.05.1951.

16 APO, KW PZPR w Opolu, sygn. 1733, Ocena kampanii Narodowego Plebiscytu Pokoju przez Egzekutywę KW PZPR Opole (Evaluation of the National Plebiscite for Peace campaign by KW PZPR Executive in Opole) [25.05.1951], unnumbered pages; ibidem, sygn. 248, Informacja Wojewódzkiego Komitetu Obrońców Pokoju z przygotowań do Narodowego Plebiscytu Pokoju z 3 V 1951 r. (Information from the Voivodeship Committee of the Defenders of Peace on Preparations for the National Plebiscite for Peace from 3 May 1951), card 30. Po zakończeniu Plebiscytu Pokoju na Opolszczyźnie (After the End of the Plebicite for Peace in Opole Region), "Trybuna Robotnicza”, 25.05.1951.

17 For example APO, KP PZPR w Głubczycach, sygn. 42/II/1, Sprawozdanie Powiatowego Komitetu Obrońców Pokoju w Głubczycach [1951 r.] (Report from Poviat Committee of the Defenders of Peace in Głubczyce [1951]), unnumbered pages. 
Field committees appointed so-called peace agitators, who were to approach voters, deliver cards to them and explain the plebiscite objective. As the First KW PZPR Secretary in Opole, Roman Nowak emphasised there was to be one agitator for every 10 to 15 persons $^{18}$. By 10 May, 34,524 such agitators had been selected ${ }^{19}$. The Voivodeship Committee of the Defenders of Peace reported that a final total of 46,148 agitators had been engaged in the plebiscite campaign, including 65 percent of independents and autochthones ${ }^{20}$.

All those actively engaged in the campaign were to be trained and get acquainted with ideological guidelines and the plebiscite objective, and they were prepared for public speeches and talks with voters. First, on 19 April the briefing of the voivodeship committee plenipotentiaries took place. Then, they trained lecturers in poviat committees who met gromady, places of work and other committee members. By 10 May, 606 seminars had been organised, in which 19,494 agitators participated ${ }^{21}$. Seminars lasted until 13 May. According to reports given by KW PZPR in Opole, 27,108 persons took part in those training sessions ${ }^{22}$. Their significance was emphasised by the First

18 APO, KW PZPR w Opolu, sygn. 248, Protokół nr 17/51 z posiedzenia Egzekutywy KW PZPR w Opolu z 4 V 1951 r. (Protocol no. 17/51 from the meeting of KW PZPR Executive in Opole from 4 May 1951), card 9.

19 AAN, KC PZPR, sygn. 237/VII-1696, Wewnętrzny Biuletyn Informacyjny Referatu Sprawozdawczego KW PZPR w Opolu z 11 V 1951 r. (Internal News Bulletin of KW PZPR Reporting Department in Opole from 11 May 1951). According to the report from the first day of the plebiscite there were 36,513 agitators. APO, KW PZPR w Opolu, sygn. 248, Informacja w sprawie przebiegu kampanii plebiscytowej z 18 V 1951 (Information on the plebiscite campaign running from 18 May 1951), card 77; ibidem, sygn. 1733, Ocena kampanii Narodowego Plebiscytu Pokoju przez Egzekutywę KW PZPR Opole (Evaluation of the National Plebiscite for Peace campaign by KW PZPR Executive in Opole) [25 May 1951], unnumbered pages.

20 APO, KW PZPR w Opolu, sygn. 1733, Ocena kampanii Narodowego Plebiscytu Pokoju przez Egzekutywę KW PZPR Opole [25 V 1951 r.] (Evaluation of the National Plebiscite for Peace campaign by KW PZPR Opole Executive [25 May 1951]). According to the report, from the first day of the plebiscite there were 55,401 of them. APO, KW PZPR w Opolu, sygn. 248, Informacja w sprawie przebiegu kampanii plebiscytowej z $18 \mathrm{~V} 1951 \mathrm{r}$. (Information on the plebiscite campaign running from 18 May 1951), card 77. The data seem to be inflated, however, and as in case of the number of KOP (see the footnote above), numbers given by WKOP at KW PZPR Executive meeting in Opole on 25 May 1952 in the action summary seem to be more credible. In 1952, WKOP announced that 45,586 persons in total had been engaged in the campaign APO, WKOP, sygn. 1, Sprawozdanie z działalności politycznej i organizacyjnej Woj. Komitetu Obrońców Pokoju w Opolu i terenowych Komitetów Obrońców Pokoju za 1951 r. (Report on political and organizational activity of the Voivodeship Committee of the Defenders of Peace in Opole and field Committees of the Defenders of Peace for the year 1951), unnumbered pages.

21 AAN, KC PZPR, sygn. 237/VII-1696, Wewnetrzny Biuletyn Informacyjny Referatu Sprawozdawczego KW PZPR w Opolu z 11 V 1951 r. (Internal News Bulletin of KW PZPR Reporting Department in Opole from 11 May 1951). See also ibidem, sygn. 237/VII-2659, Notatka Kom. Wyk. PKOP o stanie przygotowań do Narodowego Plebiscytu Pokoju na dzień 4 maja 1951 r. (Note from the PKOP Executive Committee on the state of preparations for the National Plebiscite for Peace dated 4 May 1951), card 56; APO, KW PZPR w Opolu, sygn. 248, Informacja Wojewódzkiego Komitetu Obrońców Pokoju z przygotowań do Narodowego Plebiscytu Pokoju z 3 V 1951 r. (Information from the Voivodeship Committee of the Defenders of Peace on preparations for the National Plebiscite for Peace from 3 May 1951), card 30; APO, WKOP, sygn. 1, Sprawozdanie z działalności politycznej i organizacyjnej Woj. Komitetu Obrońców Pokoju w Opolu i terenowych Komitetów Obrońców Pokoju za 1951 r. (Report on political and organizational activity of the Voivodeship Committee of the Defenders of Peace in Opole and field Committees of the Defenders of Peace for the year 1951), unnumbered pages.

22 APO, KW PZPR w Opolu, sygn. 1733, Ocena kampanii Narodowego Plebiscytu Pokoju przez Egzekutywe KW PZPR Opole [25 V 1951 r.] (Evaluation of the National Plebiscite for Peace by KW PZPR Opole Executive [25 May 1951]), unnumbered pages; ibidem, sygn. 248, card 44, Protokół z posiedzenia Egzekutywy KW PZPR w Opolu z 11 V 1951 r. (Minutes from KW PZPR Executive meeting in Opole from 11 May 1951); AAN, KC PZPR w Warszawie, sygn. 237/VII-234, Sprawozdanie z wyjazdu służbowego do woj. opolskiego z 28 V 1951 r. (Report on official trip to Opole Voivodeship from 28 May 1951), card 38. According to WKOP report from 1952, 26,173 agitators were trained. APO, WKOP, sygn. 1, Sprawozdanie z działalności politycznej i organizacyjnej Woj. Komitetu Obrońców Pokoju w Opolu i terenowych Komitetów Obrońców Pokoju za $1951 \mathrm{r}$. (Report on political and organizational activity of the Voivodeship Committee of the Defenders of Peace in Opole and field Committees of the Defenders of Peace for the year 1951), unnumbered pages. 
KW PZPR Secretary, Roman Nowak, who highlighted that agitators needed to be well prepared "for questions expected on the part of people, especially local inhabitants. All the more so that materials in the brochure published by PKOP are insufficient for the Opole area"23. Training sessions were based on the contents of the PKOP brochure - 17 Maja Narodowy Plebicyt Pokoju (17 May National Plebiscite for Peace) that contained 10 questions and answers related to the campaign. During meetings, propaganda materials were distributed, that is the content of speeches, slogans, instructions, cards, etc. ${ }^{24}$ Several days before the plebiscite, agitators went to their appointed territories and met voters. They distributed peace cards and brochures to them, explained the objective and significance of the plebiscite as well as instructed people on where and how they could vote ${ }^{25}$.

Apart from selecting and training agitators, KOPs also organised meetings with voters in respective gromady, places of work etc. They were responsible for preparing population registers to ${ }^{26}$. Written statements of inhabitants were also delivered to committees, sometimes with an attached photograph, explaining why they were signing the peace appeal27.

The National Plebiscite for Peace did not meet the standards of a typical election. Most of all, cards were received earlier from agitators, who had entered the name and surname of the person who was to submit the card. Voters signed cards, and then, in person, publicly submitted them in places designated for this purpose between 17 and 22 May. Everybody who reached the age of 15 years was allowed to submit a card. Cards were rectangular with an emblem of a dove at the top of the page.

23 APO, KW PZPR w Opolu, sygn. 248, Protokół z posiedzenia Egzekutywy KW PZPR w Opolu z 4 V 1951 r. (Minutes from KW PZPR Executive meeting in Opole from 4 May 1951), card 9.

24 Ibidem, card 77, Informacja w sprawie przebiegu kampanii plebiscytowej z $18 \mathrm{~V} 1951 \mathrm{r}$. (Information on the plebiscite campaign running from 18 May 1951); APO, KP PZPR w Głubczycach, sygn. 42/II/1, Sprawozdanie Powiatowego Komitetu Obrońców Pokoju w Głubczycach [1951 r.] (Report from Poviat Committee of the Defenders of Peace in Głubczyce [1951]), unnumbered pages.

25 APO, KW PZPR w Opolu, sygn. 1733, Ocena kampanii Narodowego Plebiscytu Pokoju przez Egzekutywę KW PZPR Opole [25 V 1951 r.] (Evaluation of the National Plebiscite for Peace campaign by KW PZPR Executive in Opole [25 May 1951]), unnumbered pages; 39 tys. aktywistów na Opolszczyźnie bierze czynny udział w przygotowaniach do Plebiscytu Pokoju (39,000 Activists in Opole Region Take Active Part in the Plebiscite for Peace Preparations), "Trybuna Robotnicza", 9 May 1951.

2620674 agitatorów...

27 APO, KP PZPR w Głubczycach, sygn. 42/II/1, Sprawozdanie Powiatowego Komitetu Obrońców Pokoju w Głubczycach [1951 r.] (Report from Poviat Committee of the Defenders of Peace in Głubczyce [1951]), unnumbered pages. 


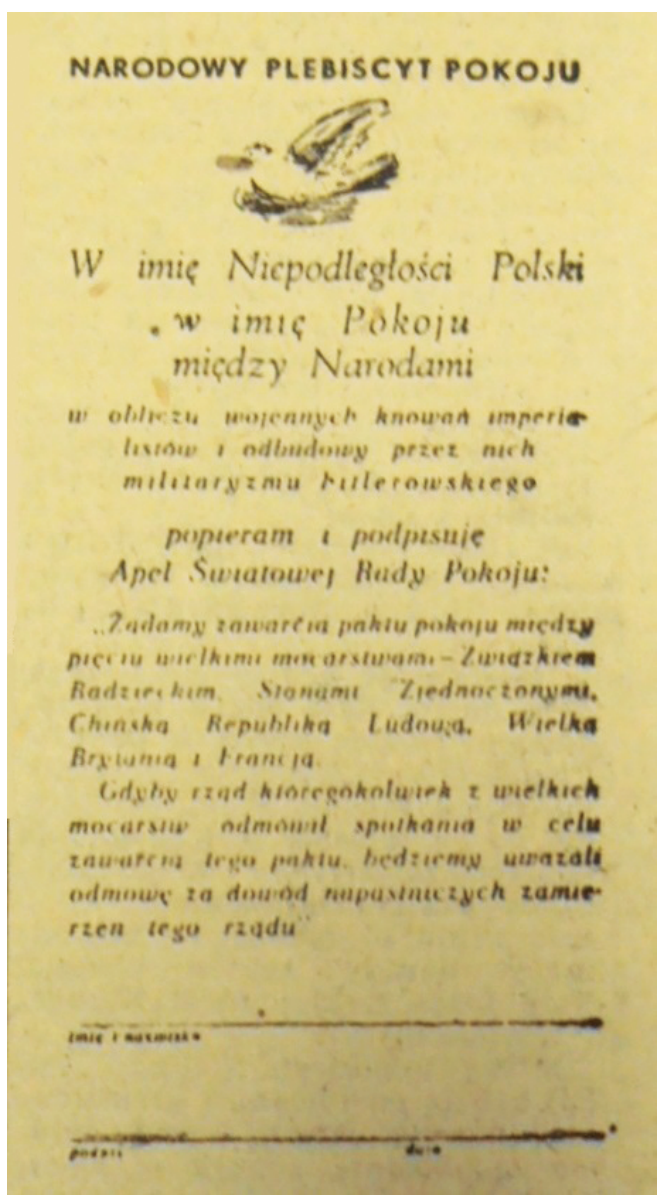

Il. 1. Card given during National Plebiscite for Peace, May 17-22, 1951, reprinted in „Dziennik Zachodni”, 17 May 1951.

Below, there was a text printed in blue:

In the name of the Independence of Poland, in the name of Peace between Nations in the face of warlike intrigues of imperialists and their attempts to rebuild Nazi militarism, I support and sign the Appeal of the World Peace Council "We demand the concluding of the peace treaty between the five great world powers - the USSR, the United States, People's Republic of China, Great Britain and France. If the government of any of these great world powers refuses to meet in order to conclude this treaty we would consider its refusal as evidence of hostile intentions" ${ }^{\prime 2}$.

At the bottom, the name and surname of the person submitting the card were written down, and below there was a place for a signature and date. Apart from cards in Polish language for Opole Voivodeship inhabitants, versions in German were also prepared $^{29}$. 
Despite official reassurance that the National Plebiscite for Peace was an initiative realised by PKOP, its conduct was strictly controlled by PZPR. In Opole Voivodeship, the matter of voting was discussed for the first time at the meeting of KW PZPR Executive on 20 April 1951. Jadwiga Ludwińska presented the objective and date of the plebiscite. It was determined that party members would enter KOPs of all levels and would be held accountable by the Party for appropriate voting management ${ }^{30}$. Before 17 May the campaign was discussed twice at extended KW meetings with the participation of the first secretaries of KP PZPR, KP PZPR Propaganda Departments managers and WKOP activists as well as directors of mass organisations. By 10 May 172 plenary meetings of municipality and city committees and 1,746 Party meetings devoted to the plebiscite (396 in places of work, 443 in city committees and 548 in gromada committees, 147 in production cooperatives) had been conducted. In total, 28,772 people participated in those meetings ${ }^{31}$. This mobilisation of party activists was undertaken, as emphasised, with the objective of avoiding the organisational shortcomings that had occurred during 1 May celebrations preparations. The role of the Party was explained by Ludwińska at the KW PZPR Organizational Department meeting in Opole:

The Plebiscite is managed only by KOPs that are entirely responsible for conducting the Plebiscite. The whole Party organisation, all KOPs must be mobilised in this campaign. The Party members should also belong to KOP. PKOPs need to be regrouped so that they could be managers conducting this campaign. If there is a place where there are no representatives of our Party in PKOP, it needs to be organised this way so that in every PKOP there is our representative [...]. The make-up of committees is a Party and state secret. Every five days, KW should receive a report on the progress of the campaign ${ }^{32}$.

These announcements were realised - Party members dominated the composition and activity of peace committees that were acting under the control and pressure of Party authorities ${ }^{33}$. The campaign was documented in quite detailed

30 APO, KW PZPR w Opolu, sygn. 247, Protokół nr 15/51 z posiedzenia Egzekutywy KW PZPR w Opolu z 20 IV 1951 r. (Protocol no. 15/51 from KW PZPR Executive meeting in Opole from 20 April 1951), card 189.

31 AAN, KC PZPR, sygn. 237/VII-1696, Wewnętrzny Biuletyn Informacyjny Referatu Sprawozdawczego KW PZPR w Opolu z 11 V 1951 r. (Internal News Bulletin of KW PZPR Reporting Department in Opole from 11 May 1951); APO, KW PZPR w Opolu, sygn. 1733, Ocena kampanii Narodowego Plebiscytu Pokoju przez Egzekutywę KW PZPR Opole [25 V 1951 r.] (Evaluation of the National Plebiscite for Peace campaign by KW PZPR Opole Executive [25 May 1951]), unnumbered pages.

32 APO, KW PZPR w Opolu, sygn. 988, Protokół z odprawy Wydziału Organizacyjnego [kwiecień 1951 r.] (Minutes from Organizational Department briefing [April 1951]), card 38.

33 See for example: APO, KM PZPR w Opolu, sygn. 50/IV/3, Sprawozdanie z akcji przygotowawczej i przebiegu Ogólnopolskiego Plebiscytu Pokoju w Opolu [1951 r.] (Report on preparatory action and running of the National Plebiscite for Peace in Opole [1951]), cards 73-77; APO, KP PZPR w Oleśnie, sygn. 49/IV/5, Sprawozdanie z przebiegu akcji plebiscytowej na terenie powiatu oleskiego (Report on the plebiscite campaign management in Olesno poviat), unnumbered pages; AAN, KC PZPR w Warszawie, sygn. 237/VII-234, Sprawozdanie z wyjazdu służbowego do woj. opolskiego z 28 V 1951 r. (Report on official trip to Opole Voivodeship from 28 May 1951), cards 36, 38. 
reports. It is worth mentioning that this was not exceptional because at that time other PZPR activities were also encompassed by a similar range of descriptions and reports. For form's sake it must be noted that Party poviat committees were to pass daily reports to $\mathrm{KW}$, referring to the Party field committees' participation in the plebiscite campaign ${ }^{34}$. KW PZPR Reporting Department in Opole would pass regular reports on the campaign to KC Party.

The broadest possible group of mass organisations, representatives of different professional and social groups were to engage in the plebiscite campaign too. The Association of Polish Youth (Związek Młodzieży Polskiej; further: ZMP), the United People's Party (Zjednoczone Stronnictwo Ludowe; further: ZSL), the Alliance of Democrats (Stronnictwo Demokratyczne; further: SD) and Vocational Training Centre members joined preparatory works. The Association of Polish Teachers (Związek Nauczycielstwa Polskiego; further: ZNP) delegated 596 teachers to take part in the campaign. The Union of Peasant Self-help (Związek Samopomocy Chłopskiej; further: ZSCh) and the League of Women also sent their representatives to the plebiscite campaign, though their participation was lower than had been expected. Those organisations' members called meetings, gave talks and lectures dedicated to the plebiscite or undertook the responsibilities of agitators themselves. In Opole Voivodeship, SD members and teachers were especially active. Young ZMP members also distinguished themselves, in some regions constituting more than a half of agitators ${ }^{35}$.

\section{Propaganda activities}

In the period under discussion, Polish society was permanently engaged in different activities and campaigns, celebrations and assemblies. The National Plebiscite for Peace coincided with several initiatives of this character. That is why its postulates were also presented on some other occasions. So, for example, the announcements about the plebiscite appeared during the campaign connected with Labour Day. Peace slogans also dominated Education, Books and Press Days held on 3-15 May.

34 See for example: APO, KP PZPR w Grodkowie, sygn. 43/VI/6, Ankieta Sprawozdawcza z przebiegu przygotowań do Plebiscytu Pokoju z 14 V 1951 r. (Reporting survey on preparations for the Plebiscite for Peace from 14 May 1951).

35 Odczyt o Plebiscycie Pokoju (Lecture on the Plebiscite for Peace), "Trybuna Robotnicza”, 11 May 1951; Idea pokoju pogłębia się wśród ludności powiatu namysłowskiego (Better Understanding of the Idea of Peace among Namysłów Poviat's Population), "Dziennik Zachodni”, 11 May 1951; Inteligencja pracujaca w Prudniku włacza się do służby dla pokoju (Working Intelligentsia in Prudnik Joins the Service for Peace), "Dziennik Zachodni”, 14 May 1951; 2790 Komitetów Obrońców Pokoju...; 20674 agitatorów...; Pozytywny stosunek opolskich rzemieślników do Frontu Narodowego i plebiscytu Pokoju (Positive Attitude of Opole Craftsmen Toward the National Front), "Dziennik Zachodni", 8 May 1951; APO, KP PZPR w Grodkowie, sygn. 43/VI/6, Sprawozdanie opisowe Powiatowego Komitetu z organizacji i przebiegu Narodowego Plebiscytu Pokoju na terenie powiatu grodkowskiego [1951 r.] (Poviat Committee descriptive report on the organisation and running of the National Plebiscite for Peace in the territory of Grodków poviat [1951]), unnumbered pages.; APO, KW PZPR w Opolu, sygn. 248, Informacja Wojewódzkiego Komitetu Obrońców Pokoju z przygotowań do Narodowego plebiscytu Pokoju z 3 V 1951 r. (Information of The Voivodeship Committee of the Defenders of Peace on preparations for the National Plebiscite for Peace from 3 May 1951), card 30 
Celebrations for the Folk Holiday (13 May) became a pretext for popularising the plebiscite and adopting resolutions on mass participation in this event ${ }^{36}$.

In the period preceding the plebiscite, rallies and assemblies were organised during which KOP members and agitators were persuading people to take part in the campaign. Some of those meetings were accompanied by artistic performances prepared, for example, by community centre groups. KOP members' speeches were preceded by sport events in this period. In some places of work, talks on the plebiscite were even organised during morning breaks. Meetings of this character were organised not only by KOPs but also by mass organisations in both cities and small villages. During these meetings, the region's inhabitants also expressed their opinions on the possible threat of war and methods of maintaining peace. The floor was given to war veterans as well as children, mainly orphans and mothers who appealed for the maintenance of peace out of concern for their offspring. Authorities recognised in the region were also referred to, such as for example Jan Wawrzynek, a pre-war Polish activist, well-known in Opole, and concentration camp survivor. Persons who, during the Second World War, had survived the occupation, as well as men of native origin who had been serving in the Wehrmacht, were listened to. Parts of those speeches were cited in the press that covered the course of pre-plebiscite meetings at length ${ }^{37}$. And for example one PGR declared: "We, tractor drivers will overcome warmongers by peaceful work and the whirr of tractors [...] we will prove that we heartily stand shoulder to shoulder for peace; we, tractor drivers are joining the plebiscite for our Homeland, in the name of the future of our children"38. One

36 Ibidem, sygn. 2066, Wydział Propagandy KW PZPR w Opolu do I Sekretarza KP PZPR w Koźlu z 26 IV 1951 r. (KW PZPR Propaganda Department in Opole to the First Secretary of KP PZPR in Koźle from 26 April 1951), cards 18-19; APO, KP PZPR w Oleśnie, sygn. 49/IV/5, Sprawozdanie z przebiegu akcji plebiscytowej na terenie powiatu oleskiego (Report on the management of the plebiscite campaign in the territory of Olesno Poviat), unnumbered pages; APO, KP PZPR w Głubczycach, sygn. 42/II/1, Sprawozdanie Powiatowego Komitetu Obrońców Pokoju w Głubczycach [1951 r.] (Report of Poviat Committee of the Defenders of Peace in Głubczyce [1951]), unnumbered pages; APO, KM PZPR w Opolu, sygn. 50/ IV/3, Protokół z posiedzenia Egzekutywy KM PZPR w Opolu z 15 V 1951 r. (Protocol on Opole KM PZPR Executive meeting from 15 May 1951), cards 172-175; Obchody Święta Ludowego z udziałem wicepremiera Korzyckiego (Folk Holiday Celebrations with the Participation of Deputy Prime Minister Korzycki), "Dziennik Zachodni", 15 May 1951.

37 Tysiace mieszkańców Opolszczyzny biora udział w przygotowaniach do Plebiscytu Pokoju (Thousands of Inhabitants of Opole Region Take Part in Preparations to the Plebiscite for Peace), "Trybuna Robotnicza", 15 May 1951; Najlepszq opiniq w pracach przygotowawczych do Narodowego Plebiscytu Pokoju cieszy się dzielnicowy KOP Opole-Zaodrze (District KOP Opole-Zaodrze Enjoys the Best Reputation in Preparatory Works to the National Plebiscite for Peace), "Dziennik Zachodni", 16 May 1951; W przygotowaniach do wielkiego plebiscytu (Preparing for the Great Plebiscite), "Dziennik Zachodni", 16 May 1951; Mieszkańcy Nysy pragna pokoju aby odbudować swoje zniszczone miasto (Nysa Inhabitants Desire Peace to Rebuild Their Destroyed City), "Dziennik Zachodni”, 17 May 1951; Z. Pocałun, Wielki dzień Paczkowa (Paczkowo Great Day), "Trybuna Robotnicza", 22 May 1951; Wszyscy ludzie pracy jednocza sie w narodowym froncie walki o pokój (All People United in the National Front of Struggle for Peace), "Dziennik Zachodni", 15 May 1951; APO, KP PZPR w Grodkowie, sygn. 43/VI/6, Sprawozdanie opisowe Powiatowego Komitetu z organizacji i przebiegu Narodowego Plebiscytu Pokoju na terenie powiatu grodkowskiego [1951 r.] (Descriptive report from Poviat Committee on the organisation and running of the National Plebiscite for Peace in the territory of Grodków Poviat [1951]), unnumbered pages; APO, KM PZPR w Opolu, sygn. 50/IV/3, Protokół z posiedzenia Egzekutywy KM PZPR w Opolu z 15 V 1951 r. (Minutes from Opole KM PZPR Executive meeting from 15 May 1951), cards 172-175.

38 APO, KP PZPR w Głubczycach, sygn. 42/II/1, Sprawozdanie Powiatowego Komitetu Obrońców Pokoju w Głubczycach [1951] (Głubczyce Poviat Committee of the Defenders of Peace Report [1951]), unnumbered pages. 
pupil at a school meeting announced: "The struggle for peace is a struggle against those who again want to destroy and take away the advances of people's democracy from us and throw us back into hopeless poverty"39. A girl who had lost her father in the war appealed: "We little children do not want to lose our fathers and brothers. We want peace forever! We ask you, parents, to do your best so that war does not break out again!"40. One factory worker in Opole asserted: "Our signatures will be sharper than a nuclear bomb; they will become the determining factor that will stop war from happening". One father pointedly expressed his protest: "I have not brought up sons for imperialists to make cannon fodder out of them"41.

Considerable attention was paid to face-to-face meetings between agitators for peace and voters. Methods employed in Brzeg were thought to be particularly pertinent - agitators did not limit themselves to leaving brochures and cards but also organized discussions with inhabitants on the subject of threats to peace ${ }^{42}$. An agitator's task was to encourage people to participate in the plebiscite and refute any possible arguments undermining its validity. Agitators were to influence all those who had given in to foreign influences, and "open the eyes of these people to the genocidal scheming of Anglo-Saxon imperialists, convince them of the rectitude of the politics of our People's Government and the Party"33. It was argued that: "An apt and convincing answer of an agitator for peace is a well-aimed shot at warmongers, shot into their lies and hostile propaganda"44. Party authorities clearly emphasised that participation in the plebiscite was voluntary and "administrative pressure in any form must not be used" toward society ${ }^{45}$. That is why attention was paid to effective agitation.

39 J. Kamiński, Zadanie, które zostanie wykonane na piq̨tkę (Task Well Done), "Trybuna Robotnicza", 20 May 1951.

40 Obchody Święta Ludowego z udziałem wicepremiera Korzyckiego (Folk Holiday Celebrations with the Participation of Deputy Prime Minister Korzycki), “Dziennik Zachodni”, 15 May 1951.

41 APO, KW PZPR w Opolu, sygn. 1733, Ocena kampanii Narodowego Plebiscytu Pokoju przez Egzekutywę KW PZPR Opole [25 V 1951 r.] (Evaluation of the National Plebiscite for Peace campaign by Opole KW PZPR Executive [25 May 1951]), card 130; AAN, KC PZPR w Warszawie, sygn. 237/VII-1678, Meldunek Referatu sprawozdawczego KW PZPR w Opolu do KC PZPR w Warszawie z 18 V 1951 r. (KW PZPR in Opole Reporting Department Account to KC PZPR in Warsaw from 18 May 1951), card 42. The same see: APO, KW PZPR w Opolu, sygn. 1733, Meldunek KW PZPR w Opolu do KC PZPR w Warszawie z 17 V 1951 r. (Opole KW PZPR report to KC PZPR in Warsaw from 17 May 1951), cards 107-109.

42 APO, WKOP, sygn. 1, Sprawozdanie z działalności politycznej i organizacyjnej Woj. Komitetu Obrońców Pokoju w Opolu i terenowych Komitetów Obrońców Pokoju za 1951 r. (Report on political and organisational activity of the Voivodeship Committee of the Defenders of Peace in Opole and field Committees of the Defenders of Peace for the year 1951), unnumbered pages.

43 Podpis na karcie plebiscytowej - to głos przeciwko wojnie (A signature on a Plebscite Card - Means One Vote against War), "Trybuna Robotnicza”, 14 May 1951.

44 Ibidem.

45 APO, KP PZPR w Grodkowie, sygn. 43/VI/6, Sprawozdanie opisowe Powiatowego Komitetu z organizacji i przebiegu Narodowego Plebiscytu Pokoju na terenie powiatu grodkowskiego [1951 r.] (Descriptive report from Poviat Committee on the organisation and running of the National Plebiscite for Peace in the territory of Grodków Poviat [1951]), unnumbered pages. See also: APO, KW PZPR w Opolu, sygn. 988, Protokół z odprawy Wydziału Organizacyjnego [kwiecień 1951 r.] (Minutes of the Organizational Department briefing [April 1951]), cards 32, 38. 
Propaganda rhetoric before the plebiscite used among others a statement that the guarantee of world peace is the group of states gathered around the USSR. The United Stated and Great Britain were identified as special threats to peace. Similarly was treated a broadly understood group of capitalists who were thought to be counting on profits coming from potential armed conflict. The opposing camp was most often described as "warmongers" or "imperialists". The participation of the United States in the Korean War was treated as evidence of this state's criminal activities. The United States was eagerly pointed to as a country of social exploitation, in which the living standards of average citizens were very low. In Opole Voivodeship, where German sentiments were still alive, references to Western Germany took on a special meaning regarding the campaign. A signature as part of the Berlin Appeal was presented as an expression of protest against activities aimed at the remilitarisation of the German Federal Republic, Wehrmacht reconstruction and Nazi generals' and war criminals' release from prisons. These activities violated peace because they were caused by revisionist endeavours of Western Germany that had planned the attack on Poland's Western Territories ${ }^{46}$. It was emphasised that everybody ought to sign cards because every single vote as part of The World Peace Council Appeal was significant. The attention of people was drawn to the fact that the campaign had a mass character and similar activities were also being undertaken in other countries. Time and again before the plebiscite, it was argued that a signature as part of the Berlin Appeal was an expression of acceptance of the direction political and economic changes were taking in Poland. War might stop these changes. The plebiscite campaign was cleverly combined with the campaign to popularise the Six-Year Plan, explaining that increased productive effort would resulted in the improvement of the country's condition and defensive capability. The slogan "struggle for peace", de facto of oxymoronic character, was often referred to. Quite simple slogans were used, e.g. "Whoever desires happiness for themselves and their loved ones signs the peace appeal" or "The accomplishment of the Six-Year Plan will be the best answer to Anglo-American imperialists' scheming", "Glory to Fighters in the struggle for peace!", "Viva Joseph Stalin, the Ensign of Peace", "Shame on warmongers, villains of the people!"

As part of the campaign conducted to celebrate the National Plebiscite for Peace, production commitments were undertaken, so-called peace guards. The initiatives aimed at increasing work effort were a permanent element of other campaigns and ceremonies. They were undertaken for example on International Women's Day, Labour Day,

46 See for example: A.M., Śladami karty pokoju (Following the Peace Card), "Trybuna Robotnicza", 22 May 1951; APO, KP PZPR w Grodkowie, sygn. 43/VI/6, Sprawozdanie opisowe Powiatowego Komitetu z organizacji i przebiegu Narodowego Plebiscytu Pokoju na terenie powiatu grodkowskiego [1951 r.] (Poviat Committee descriptive report on the organisation and running of the National Plebiscite for Peace in the territory of Grodków Poviat [1951]), unnumbered pages.

47 APO, KP PZPR w Grodkowie, sygn. 43/VI/6, Sprawozdanie opisowe Powiatowego Komitetu z organizacji i przebiegu Narodowego Plebiscytu Pokoju na terenie powiatu grodkowskiego [1951 r.] (Poviat Committee descriptive report on the organisation and running of the National Plebiscite for Peace in the territory of Grodków Poviat [1951]), unnumbered pages; Dzień Plebiscytu w Śląskich Zakładach Obuwia w Otmęcie (The Plebiscite Day in Silesian Footwear Factory in Otmęt), “Trybuna Robotnicza”, 20 May 1951. 
22 July, etc. Most of all, the biggest industrial plants, production cooperatives, sand tate agricultural farms joined the campaign of commitments before the plebiscite. Commitments were taken individually or in groups. Within these activities personnel declared working extra hours, implementing rationalisation solutions, and savings. Villages planned, among others, to sow fallows, increase milk deliveries, clean melioration ditches, and tidy homesteads. The majority of commitments applied to the faster conclusion or earlier beginning of planned activities. Officially, the value of declared works to celebrate the plebiscite in Opole Voivodeship was estimated at one million zloty ${ }^{48}$.

The campaign before the plebiscite also embraced children who were younger than 15 years old, mainly school pupils. With the participation of parent committees and most of all teachers at schools, a campaign was organised to promote peace slogans. Special lessons were conducted, during which the ideological assumptions of defenders of peace movement were presented. Bulletin boards on anti-war subjects were prepared ${ }^{49}$. Pupils of almost all schools were writing written compositions entitled Why do we fight for peace? - selected works were published in "Dziennik Zachodni" ${ }^{\circ}$. Special mass meetings for schools were organised. For example, in Opole on 12 May on Red Army Square (currently Mikołaj Kopernik Square) all schools paraded, walking along the streets, carrying flags and cheering for peace ${ }^{51}$. Younger classes agreed resolutions, in which they emphasised their support for peace activities, spoke against war or declared that good school outcomes would be their contribution in the struggle for peace. Pupils of the primary school in Luboszyce wrote in their resolution:

48 AAN, KC PZPR, sygn. 237/VII-1696, Wewnętrzny Biuletyn Informacyjny Referatu Sprawozdawczego KW PZPR w Opolu (Internal News Bulletin of KW PZPR Reporting Department in Opole) from 14 May 1951; APO, KW PZPR w Opolu, sygn. 1733, Ocena kampanii Narodowego Plebiscytu Pokoju przez Egzekutywę KW PZPR Opole [25 V 1951 r.] (Evaluation of the National Plebiscite for Peace campaign by Opole KW PZPR Executive [25 May 1951]), unnumbered pages; Zobowiqzanie i apel racjonalizatorów Cementowni "Odra" (Odra Cement Factory Commitment and Appeal of Rationalizers), "Dziennik Zachodni", 9 May 1951; Obchody Święta Ludowego z udziałem wicepremiera Korzyckiego (Folk Holiday Celebrations with the Participation of Deputy Prime Minister Korzycki), "Dziennik Zachodni", 15 May 1951; J. Bałłaban, Młodzieżowe Warty Pokoju w Zakładach Przemysłu Dziewiarskiego w Głuchołazach (Youth Peace Guards in Knitting Industry Factory in Głuchołazy), "Dziennik Zachodni”, 17 May 1951; Manifestacyjny udział społeczeństwa opolskiego w Narodowym Plebiscycie Pokoju (Demonstrative Participation of Opole Society in the National Plebiscite for Peace), "Trybuna Robotnicza", 18 May 1951; Będziemy utrwalać pokój (We Will Make the Peace Last), "Dziennik Zachodni”, 14 May 1951; 39 tys. aktywistów...; Plebiscyt - potężnq manifestacja pokoju (The Plebiscite - Great Manifestation of Peace), "Dziennik Zachodni", 19 May 1951; Plebiscyt zakończony - Warty Pokoju w ZPA trwajq nadal (The End of the Plebiscite - Peace Guards in ZPA Still on the Watch), “Trybuna Robotnicza”, 23 May 1951.

49 AAN, KC PZPR, sygn. 237/VII-1696, Wewnętrzny Biuletyn Informacyjny Referatu Sprawozdawczego KW PZPR w Opolu (Internal News Bulletin of KW PZPR Reporting Department in Opole) from 14 May 1951; Tysiqce mieszkańców Opolszczyzny biorq udział w przygotowaniach do Plebiscytu Pokoju (Thousands of Opole Region Inhabitants Take Part in Preparations for the Plebiscite for Peace), "Trybuna Robotnicza", 15 May 1951; J. Kamiński, op. cit.

50 Dlaczego walczymy o pokój? (Why do we Fight for Peace?), "Dziennik Zachodni”, 18 May 1951.

51 Młodzieżowy pochód pokoju na ulicach Opola (Youth Peace March in Opole Streets), "Dziennik Zachodni", 15 May 1951. 
We schoolchildren in Luboszyce together with our tutors will be struggling for peace till our last death and fighting the vile scheming of imperialists. Viva the nations united in the struggle for peace with the USSR at the head. Viva young people of the world standing in the first rows of defenders for peace $!^{52}$

In some schools, separate plebiscites were conducted so that older pupils could be role models for the younger at school who could also speak against war. Pupils from schools in Nowa Wieś Królewska and Grudzice collected cards prepared by themselves $^{53}$. These activities, though presented as spontaneous, were de facto centrally controlled, realised according to Party instructions ${ }^{54}$. Engaging pupils in campaigns was aimed at shaping not only their attitudes - children were also to convey slogans and messages from school to their homes and persuade parents and other relatives or neighbours to participate in the plebiscite ${ }^{55}$.

Participation of clergy was an essential element of the plebiscite campaign. Authorities had much interest in priests and nuns not only submitting their cards but also joining agitation ${ }^{56}$. Church authorities allowed clergy the freedom to choose whether to participate in the plebiscite. They were allowed to take part in KOP activities but they were not permitted to act as agitators for peace ${ }^{57}$. In connection with that, members of the Church were often persuaded during sermons to take part in the plebiscite and speak against war. In the territory of Opole Voivodeship, 105 priests joined KOPs. A peace committee even came into existence at the seminary in Opole. Many examples of priests' engagement in the plebiscite were described in press, and discussed at peace or Party committees meetings ${ }^{58}$. Taking

52 AAN, KC PZPR, sygn. 237/VII-1696, Wewnętrzny Biuletyn Informacyjny Referatu Sprawozdawczego KW PZPR w Opolu z 22 V 1951 r. (Internal News Bulletin of KW PZPR Reporting Department in Opole from 22 May 1951).

53 Jak dzieci z Nowej Wsi Królewskiej podpisały Apel Pokoju (Children from Nowa Wieś Królewska Signing the Peace Appeal), “Trybuna Robotnicza”, 22 May 1951.

54 APO, KP PZPR w Głubczycach, sygn. 42/II/1, Sprawozdanie Powiatowego Komitetu Obrońców Pokoju w Głubczycach [1951 r.] (Report of Poviat Committee of the Defenders of Peace in Głubczyce [1951]), unnumbered pages.

55 Vide statement by Jan Pasek from the Education Department of the National Council Presidium: APO KP PZPR w Raciborzu, sygn. 53/II/1, Protokół z posiedzenia plenum KP PZPR w Raciborzu z 14 V 1951 r. (Minutes of KP PPR plenum meeting in Racibórz from 14 May 1951), unnumbered pages.

56 This problem deserves to be elaborated, that is why it will only be briefly presented in this place.

57 Archiwum Diecezjalne w Opolu (Diocesan Archives in Opole), “Księża patrioci” w PRL (Priests Patriots in Polish People's Republic), sygn. 12/1, Pro memoria w sprawie akcji pokojowej [7 V 1951 r.] (Pro Memoria on the Peace Campaign [7 May 1951]), unnumbered pages.

58 APO, KW PZPR w Opolu, sygn. 1733, Ocena kampanii Narodowego Plebiscytu Pokoju przez Egzekutywę KW PZPR Opole [25 V 1951 r.] (Evaluation of the National Plebiscite for Peace campaign by Opole KW PZPR Executive [25 May 1951]), unnumbered pages; AAN, KC PZPR w Warszawie, sygn. 237/VII-1678, Meldunek sytuacyjny w związku z Plebiscytem Pokoju na terenie województwa opolskiego z 17 V 1951 r (Situational report in connection with the Plebiscite for Peace in the territory of Opole Voivodeship from 17 May 1951), card 41; APO, KM PZPR w Opolu, sygn. 50/IV/4, Ocena sytuacji politycznej na terenie miasta Opola w m-cu maju 1951 r. (Evaluation of political situation in the area of Opole city in May 1951), card 430; Duchowieństwo opolskie w obronie pokoju (Clergy in Opole in Defence of Peace), 
into account the tense relations between the authorities and the Church at that time, this cooperation during the National Plebiscite for Peace was somewhat exceptional. Certainly the participation of clergy in the campaign influenced attitudes of society and decided its results to some extent.

The press had an important task of popularising the idea of the National Plebiscite for Peace. News from Opole Voivodeship were profusely presented in "Trybuna Robotnicza" and "Dziennik Zachodni" that also described both preparations and the running of the plebiscite at length. Articles on this campaign were permeated with competitive spirit. In the course of preparations, the press informed the public about progress in establishing KOPs. Regions where the campaign was conducted in the most efficient manner were mentioned, as well as those that turned out to be the least engaged in those activities. On days of card submission people were informed how many cards had already been placed at the same time emphasising which factory, gromada or KOP finished the campaign in the first place. Information on the training schedule for agitators, rallies or broadcasting of films about the plebiscite, was printed too. Rallies, manifestations and meetings with agitators that had taken place in private homes were described. Outstanding KOP plenipotentiaries and agitators' profiles were presented ${ }^{59}$. In "Dziennik Zachodni" the cycle entitled Przed Narodowym Plebiscytem Pokoju (Before the National Plebiscite for Peace) was published. It contained opinions justifying the significance of voting that came from persons of different background and origin - Edmund Osmańczyk from Opole was one of those who had expressed their views ${ }^{60}$. In the Opole supplement to "Trybuna Robotnicza", letters sent from voivodeship inhabitants were printed. They were answers to the question Why will I sign the appeal of the World Peace Council? Presented statements came from representatives of different social groups - workmen, peasants, students, priests, the

“Trybuna Robotnicza”, 14 May 1951; W. Kaniak, Ksiq̨dz-patriota (Priest - Patriot), "Trybuna Robotnicza”, 21 May 1951; Duchowieństwo i działacze katoliccy Opolszczyzny włączyli się do walki o pokój (Catholic Clergy and Activists Joined the Campaign for Peace), "Trybuna Robotnicza", 24 May 1951; Katolicy polscy jednoczq się wokół żq̨ań Narodowego Plebiscytu Pokoju (Polish Catholics United Around the National Plebiscite for Peace Demands), "Trybuna Robotnicza”, 20 May 1951. (the same in: Ogólnopolska konferencja intelektualistów i działaczy katolickich (Polish Conference of Catholic Intellectuals and Activists), "Dziennik Zachodni", 20 May 1951).

59 Wszyscy ludzie pracy jednoczq się w narodowym froncie walki o pokój (All People of Work United in the National Front of Struggle for Peace), "Dziennik Zachodni”, 15 May 1951; Agitatorzy pokoju w akcji (Agitators in Action), "Trybuna Robotnicza”, 16 May 1951; Wszyscy podpiszemy Apel Pokoju (All of Us Will Sign the Peace Appeal), "Trybuna Robotnicza", 15 May 1951; Aby już nigdy żołdak faszystowski nie zabijał dzieci (So That no Nazi Soldier Will Kill Children Anymore), "Trybuna Robotnicza”, 17 May $1951 ;$ Sportowcy Opolszczyzny wezmq udział w Plebiscycie (Sportsmen of Opole Region Will Take Part in the Plebiscite), "Trybuna Robotnicza", 16 May 1951; Komitety Obrońców Pokoju dekorujq lokale do głosowania w gromadach pow. Namysłowskiego (Committees of the Defenders of Peace are Decorating Polling Stations in Gromady of Namysłów Poviat), "Dziennik Zachodni”, 14 May 1951; Opolszczyzna w pełni przygotowana do należytego przeprowadzenia Plebiscytu Pokoju (Opole Region Fully Prepared for the Proper Conduct of the Plebiscite for Peace), "Dziennik Zachodni”, 10 May 1951; Pamiętny dzień Czerwieńcic (The Memorable Day of Czerwieńcice), "Trybuna Robotnicza”, 21 May 1951; Plebiscyt-potężnq manifestacjq pokoju (The Plebiscite - Powerful Peace Demonstration), “Dziennik Zachodni”, 19 May 1951; Złożyli podpisy pod Apelem Pokoju gdyż chcq się uczyć i brać udział w twórczej pracy (They Signed the Peace Appeal because they Want to Study and Participate in Creative Work), "Trybuna Robotnicza”, 18 May 1951. 
intelligentsia, housewives, and sportsmen ${ }^{61}$. These voices repeated the appeals to sign the World Peace Council Appeal, condemned "American imperialists"' war pursuits, and emphasised the achievements of the USSR for the movement of the defenders of peace. Among others, statements of autochthones of the region were cited, who had condemned the militarisation of Western Germany and "Anglo-American capital penetration" in this country ${ }^{62}$. A pre-war Polish researcher talking about the Silesian Uprisings and the 1921 elections argued: "The struggle for peace is the struggle with the same international capitalism of Germany, England or America that deceived us in the Silesian plebiscite". Another autochthone acted as a spokesman for the Polish authorities' successes in Silesia: "There are enemies who claim that a workman or Polish peasant are not able to achieve anything, that only German masters managed to do a lot". In his opinion, the successes of the Polish authorities should have been shown to these people as well as the significance of the Six-Year Plan because thanks to these very facts "they would understand the importance of peace" ${ }^{\prime \prime 3}$.

In the campaign before the plebiscite films were also used. Beginning from 9 May in Opole Voivodeship the film Popieramy i podpisujemy Apel Światowej Rady Pokoju (We Support and Sign the Appeal of the World Peace Council) was shown. It was presented free of charge, usually in the open air, in both cities and small towns, and productive cooperatives. Over 200 screenings were planned. Other materials were shown too, mainly pictures of economic and cultural achievements after the war in Opole Voivodeship. Every performance was preceded by a speech by an agitator, who would explain the meaning and objectives of the plebiscite ${ }^{64}$. At the initiative of Opole KW PZPR Propaganda Department, a Polish Film crew came to the territory of the voivodeship, and recorded the submission of cards in Wójtowa Wieś near Opole. Later, the material became part of one of the episodes of the Polish Film Chronicles ${ }^{65}$.

61 Ludność Opolszczyzny mówi o znaczeniu plebiscytu (People of Opole Region Are Talking About the Significance of the Plebiscite), "Trybuna Robotnicza", 8 May 1951.

62 Przodownicy pracy i racjonalizatorzy mówiq o Narodowym Plebiscycie Pokoju (Lead Workers and Rationalizers are Talking About the National Plebiscite for Peace), "Dziennik Zachodni", 8 May 1951.

63 „Wszyscy pragniemy w spokoju budować lepsza przyszłość” - mówiq mieszkańcy Opolszczyzny przygotowujqc się do Plebiscytu ("All of us desire to build a better future in peace" - So Say the Inhabitants of Opole Region Preparing for the Plebiscite), "Trybuna Robotnicza", 16 May 1951.

64 Terminarz wyświetlania filmu w województwie opolskim (Schedule of Film Screenings in Opole Voivodeship), "Dziennik Zachodni", 10 May 1951; Najlepszq opiniq w pracach przygotowawczych do Narodowego Plebiscytu Pokoju cieszy się dzielnicowy KOP Opole-Zaodrze (Opole-Zaodrze District KOP Enjoys the Best Reputation in Preparatory Works for the National Plebiscite for Peace), "Dziennik Zachodni", 16 May 1951; 39 tys. aktywistów...; APO, KM PZPR w Opolu, sygn. 50/IV/3, Protokół z posiedzenia Egzekutywy KM PZPR w Opolu z 15 V 1951 r. (Minutes from Opole KM PZPR Executive meeting from 15 May 1951), cards 172-175.

65 APO, KW PZPR w Opolu, sygn. 248, Protokół nr 20/51 z posiedzenia Egzekutywy KW PZPR w Opolu z 18 V 1951 r. (Protocol no. 20/51 from Opole KW PZPR Executive meeting from 18 May 1951), cards 74-79; ibidem, Protokół z posiedzenia Egzekutywy KW PZPR w Opolu z 11 V 1951 r. (Protocol from Opole KW PZPR Executive from 11 May 1951), card 44; Uroczyste składanie kart plebiscytowych $w$ Wójtowej Wsi (Ceremonial Plebiscite Cards Submission in Wójtowa Wieś), "Dziennik Zachodni", 23 May 1951; Jednościa silni wywalczymy pokój, Polska Kronika Filmowa nr 22/5 (We Will Gain Peace Strong in Unity, Polish Film Chronicles no. 22/5), http://www.repozytorium.fn.org.pl/?q=pl/no.de/7851 (accessed: 30 July 2017). 
Broadcasting centres were also used to popularise the plebiscite in cities. Peace slogans and appeals for cards to be submitted were transmitted, and later also voting results. To celebrate the plebiscite, in Kędzierzyn Nitrogen Plant the company orchestra gave a concert every day in a different department from $15 \mathrm{May}^{66}$. In Głubczyce, on 13 May, a ride-by of ZMP members on bicycles decorated with peace slogans was planned ${ }^{67}$. In villages, city-village communication teams actively participated in preparations.

Special decorations formed the backdrop to the plebiscite. Mainly posters and slogans promoting peace, and portraits and quotations from Bolesław Bierut and "the ensign of peace" Joseph Stalin were displayed. Banners as well as flags (red ones most of all) were hung out. A frequent motif of the plebiscite decor was a white dove of peace. Places where cards were being submitted as well as community centres, premises, shop windows, places of work, office buildings, schools, factories, and less often private houses, were decorated in the first place. As noted, decorations prepared for the plebiscite were better than those organized several weeks earlier on 1 May. Some KOP points were exceptionally pleasantly decorated - in Chrząstowice, Maciejowice, Więcmierzyce, some in Brzeg, Strzelce Opolskie, Opole and Polish and the Soviet Friendship Society community centre in Grodków, and the League of Women community centre in Otmuchów. Decorations were colourful and ingenious, and made at little cost - for example flowers were used and doves were cut out of waste paper. For lack of banners or posters, plebiscite slogans were painted in some cases directly on buildings. By contrast, Kędzierzyn Nitrogen Industry Plant was richly decorated. Over the entrance an inscription was installed: The National Plebiscite for Peace 17 May 1951 - Everybody signs the Appeal of the World Peace Council. Opposite the administration building, a Peace Tower was erected with an enormous globe encircled by two white doves, moving by means of a special mechanism ${ }^{68}$.

66 Plebiscyt - potężnq manifestacja pokoju (The Plebiscite - Powerful Manifestation of Peace), "Dziennik Zachodni", 19 May 1951.

67 APO, KP PZPR w Głubczycach, sygn. 42/II/1, Sprawozdanie Powiatowego Komitetu Obrońców Pokoju w Głubczycach [1951 r.] (Report of Poviat Committee of the Defenders of Peace in Głubczyce [1951]), unnumbered pages.

68 APO, KW PZPR w Opolu, sygn. 1733, Ocena kampanii Narodowego Plebiscytu Pokoju przez Egzekutywę KW PZPR Opole [25 V 1951 r.] (Evaluation of the National Plebiscite for Peace campaign by Opole KW PZPR Executive [25 May 1951]), unnumbered pages; ibidem, sygn. 248, Informacja w sprawie przebiegu kampanii plebiscytowej z 18 V 1951 r. (Information on the running of the plebiscite campaign from 18 May 1951), card. 77; APO, KP PZPR w Raciborzu, sygn. 53/II/1, Sprawozdanie przebiegu plebiscytu narodowego na terenie Raciborza (Report on the running of the National Plebiscite in the territory of Racibórz), unnumbered pages; APO, KP PZPR w Grodkowie, sygn. 43/VI/6, Sprawozdanie opisowe Powiatowego Komitetu z organizacji i przebiegu Narodowego Plebiscytu Pokoju na terenie powiatu grodkowskiego [1951 r.] (Descriptive report from the Poviat Committee on the organization and running of the National Plebiscite for Peace in the territory of Grodków Poviat), unnumbered pages; APO, KM PZPR w Opolu, sygn. 50/IV/3, Sprawozdanie z akcji przygotowawczej i przebiegu Ogólnopolskiego Plebiscytu Pokoju w Opolu [1951 r.] (Report on the preparatory action and running of the National Plebiscite for Peace in Opole [1951]), cards 73-77; AAN, KC PZPR w Warszawie, sygn. 237/VII-234, Sprawozdanie z wyjazdu służbowego do woj. opolskiego z 28 V 1951 r. (Report on an official trip to Opole Voivodeship from 28 May 1951), cards 36, 38; Plebiscyt - potężnq manifestacjq pokoju (The Plebiscite - Powerful Manifestation of Peace), "Dziennik Zachodni", 19 May 1951; Opolszczyzna uroczyście powita dzień Plebiscytu Pokoju (Opole Region Will Welcome the Day of the Plebiscite for Peace with Due Ceremony), "Trybuna Robotnicza", 16 May 1951; Powiat namysłowski żyje sprawq obrony pokoju (The Defence of Peace Issue is the Life of Namysłów Poviat), "Trybuna Robotnicza", 20 May 1951; Za pokojem - przeciw podżegaczom wojennym... (For Peace - Against Warmongers...), “Trybuna Robotnicza”, 20 May 1951; Wielkie dni Plebiscytu Pokoju na Opolszczyźnie (Great Days of the Plebiscite for Peace in Opole Region), “Trybuna Robotnicza”, 20 May 1951. 
It is worth mentioning that the specificity of Opole region required certain intuition, carefulness and accuracy when it came to the selection of decoration motifs. For example, posters hung in Olesno Poviat showing the German Wehrmacht caused panic. They were hung without any consultation with the KP PZPR Propaganda Department which ordered they were removed as soon as possible ${ }^{69}$.

The plebiscite propaganda reached its peak on 16 May. On this day, in all places of work mass meetings were planned, during which personnel undertook resolutions on their joint, demonstrative submission of cards in the National Plebiscite for Peace. In the evening, capstrzyki ${ }^{70}$ for young people, artistic performances in community centres and talks were organised. Songs about peace were sung in front of KOPs. In Opole a rally of working intelligentsia was planned in the State Theatre of Opole on 16 May. A bonfire and performances by artistic bands were organized for young people at Ferdinand Foch Square (currently known as Joseph Piłsudski Square). In some cities (e.g. Opole, Strzelce Opolskie, Prudnik and Głubczyce) rallies and capstrzyki turned into "spontaneous demonstrations". A similar situation took place in Grodków where, according to a KOP report, "young people and workmen passing by marching were chanting «Peace, Stalin, Bierut»"71.

\section{Voting}

In the territory of Opole Voivodeship, 3,311 polling stations were made available for voting (199 in cities, 993 in gromady, 1,103 at places of work, 632 at schools, 269 in offices, 102 at cooperatives, 13 in State Machine Centres) ${ }^{72}$. Those places could not be located in administrative buildings so they were most often organised at schools, community centres, in some districts even in private flats ${ }^{73}$. Though primarily it was

69 APO, KP PZPR w Oleśnie, sygn. 49/IV/5, Sprawozdanie z przebiegu akcji plebiscytowej na terenie powiatu oleskiego (Report on running of the plebiscite action in the territory of Olesno Poviat), unnumbered pages.

70 Capstrzyk - ceremonial march by the army or members of an organisation along the streets, most often accompanied by an orchestra.

71 APO, KP PZPR w Grodkowie, sygn. 43/VI/6, Sprawozdanie opisowe Powiatowego Komitetu z organizacji i przebiegu Narodowego Plebiscytu Pokoju na terenie powiatu grodkowskiego [1951 r.] (Poviat Committee descriptive report on the organization and running of the National Plebiscite for Peace in the territory of Grodków Poviat [1951]), unnumbered pages. On mass meetings from 16 May see also: AAN, KC PZPR w Warszawie, sygn. 237/VII-234, Sprawozdanie z wyjazdu służbowego do woj. opolskiego z 28 V 1951 r. (Report on the official trip to Opole Voivodeship from 28 May 1951), card 39; APO, KW PZPR w Opolu, sygn. 1733, Ocena kampanii Narodowego Plebiscytu Pokoju przez Egzekutywę KW PZPR Opole [25 V 1951 r.] (The National Plebiscite for Peace campaign evaluation by Opole KW PZPR Executive), unnumbered pages; APO, KM PZPR w Opolu, sygn. 50/IV/3, Sprawozdanie z akcji przygotowawczej i przebiegu Ogólnopolskiego Plebiscytu Pokoju w Opolu [1951 r.] (Report on the preparatory campaign and running of the National Plebiscite for Peace in Opole [1951]), cards 73-77; Tysiace mieszkańców Opolszczyzny biorq udział w przygotowaniach do Plebiscytu Pokoju (Thousands of Opole Region Inhabitants Take Part in Preparations for the Plebiscite for Peace), "Trybuna Robotnicza”, 15 May 1951; Wielki wiec inteligencji pracujacej (Great Rally of Working Intelligentsia), “Dziennik Zachodni”, 18 May 1951.

72 Plebiscyt na Opolszczyźnie - zakończony (The Plebiscite in Opole Region - Finished), "Trybuna Robotnicza", 23 May 1951.

73 APO, KP PZPR w Raciborzu, sygn. 53/II/1, Sprawozdanie przebiegu plebiscytu narodowego na terenie Raciborza (Report on the running of the National Plebiscite in the territory of Racibórz), unnumbered pages; $W$ przygotowaniach do wielkiego plebiscytu (Preparing for the Great Plebiscite), "Dziennik Zachodni", 16 May 1951. 
assumed that village inhabitants would take part in the plebiscite most of all on Sunday 20 May, it turned out that the majority of votes were gathered during the first days - by 17 May, 60 per cent of qualified voters had participated and the next day this number reached 77 per cent. It was reported from the territory of voivodeship that prearranged voting schedules had been disturbed because many people had appeared with their cards earlier. At some polling stations people were gathering almost from dawn. The first area to finish voting, on 18 May, was Grodków Poviat, next day in Niemodlin Poviat. By as early as at eight o'clock on 17 May all votes had been collected in Żerkowice and Radomirowice ${ }^{74}$. According to official reports, the voivodeship inhabitants took part "eagerly, voluntarily, joyfully, usually demonstratively" in the plebiscite. At polling stations, all gromada inhabitants appeared in some cases. PGR workers and factory staff submitted their cards together. The idea of the plebiscite met with appreciation from guests from abroad: "Two German women appreciated the fact of the due understanding of the struggle for peace. They were staying as guests at their acquaintances' in the territory of Kuźnia Raciborska municipality. Not understanding Polish, they came to the KOP municipal committee, asked for cards, and signed them"75.

TWOJA BRON W WALCE O POKOJ

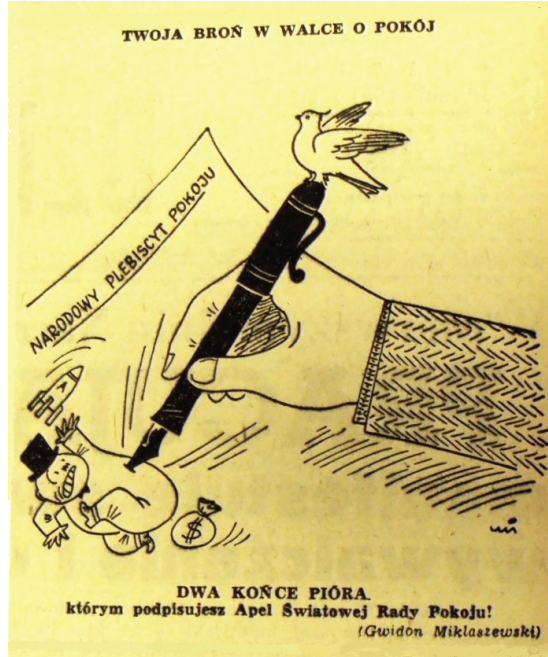

Il. 2. Satirical drawing on

National Plebiscite for Peace by

Gwidon Miklaszewski, „Dziennik

Zachodni", 18 May 1951.

74 APO, KW PZPR w Opolu, sygn. 1816, Sprawozdanie z kontroli powiatu opolskiego po linii Narodowego Plebiscytu jak również szkolenia partyjnego od dnia 12-19 V 1951 r. (Report on the control of Opole Poviat in connection with the National Plebiscite as well as Party training from 12-19 May 1951), cards 51-52; Pierwszy meldunek plebiscytowy z woj. Opolskiego (The First Plebiscite Account from Opole Voivodeship), “Dziennik Zachodni”, 18 May 1951.

75 APO, KP PZPR w Raciborzu, sygn. 53/II/1, Protokół z posiedzenia plenum KP PZPR w Raciborzu z 22 V 1951 r. (Minutes of KP PZPR plenum meeting in Racibórz), unnumbered pages. A similar case was also noted in Biedrzychowice, APO, KW PZPR w Opolu, sygn. 1733, Ocena kampanii Narodowego Plebiscytu Pokoju przez Egzekutywę KW PZPR Opole [25 V 1951 r.] (Evaluation of the National Plebiscite for Peace campaign by Opole KW PZPR Executive [25 May 1951]), card 131. 
The moment of voting itself was to proceed in a festive atmosphere so in many cases it was accompanied by singing, concerts or declamations (at one locality ballet performances were organised), prepared earlier most often by school or community centre artistic groups. Some staff, mainly from production cooperatives or PGRs, came to polling places in carts decorated with greenery and peace slogans or in a parade-like manner. Marches with flags called szturmówka, during which doves were set free and slogans in honour of peace and Stalin were chanted, were organised, for example, in Tułowice, Większyce, Karowice, Rybna, Trzebieszowice, Modzurów and Czerwińczyce ${ }^{76}$. Along with the beginning of the plebiscite in some cities youth demonstrations were summoned, for example students were picketing in the morning near the town hall in Namysłów. In Koźle they organized a march with banners, caricatures and flags ${ }^{77}$. In some cities, for instance in Opole and Racibórz, artistic performances were prepared for the afternoon and in Głubczyce - gymnastics shows. Folk dances were arranged in villages ${ }^{78}$.

Press reports on the running of the plebiscite were full of enthusiasm and evidence of social support for its idea. Information on persons who had not taken part in voting was totally ignored. Instead, detailed data referring to the number of collected cards from particular poviats were given, with the emphasis put on places where 100 per cent of votes were registered. People were informed about voting at places of work and by individual professional groups (e.g. craftsmen, barristers). Priests participating in the plebiscite were mentioned too. Voting results were transmitted via radio. Radio centres prepared a special programme on the occasion of the plebiscite - an appropriately selected music repertoire was enriched by talks on peace and data on the number of collected cards. In Paczków, announcements on the course of voting were broadcast from cars equipped with megaphones that drove around the city on the first day of the plebiscite ${ }^{79}$.

76 APO, KP PZPR w Raciborzu, sygn. 53/II/1, Sprawozdanie przebiegu plebiscytu narodowego na terenie Raciborza (Report on the running of the National Plebiscite in the territory of Racibórz), unnumbered pages; S. Ostrowski, Manifestacyjny przebieg Plebiscytu w powiecie kozielskim (Demonstrative Running of the Plebiscite in Koźle Poviat), "Trybuna Robotnicza”, 22 May 1951; Składanie kart plebiscytowych na Opolszczyźnie wspaniałq manifestacjq pokojowq (Plebiscite Cards Submission in Opole Region - Great Peace Manifestation), "Trybuna Robotnicza”, 22 May 1951; Pierwszy dzień Narodowego Plebiscytu Pokoju na Opolszczyźnie (The First Day of the National Plebiscite for Peace in Opole Region), "Dziennik Zachodni", 18 May 1951.

77 Plebiscyt - potężnq manifestacjq pokoju (The Plebiscite - Great Manifestation of Peace), "Dziennik Zachodni", 19 May 1951; Powiat namysłowski żyje sprawq obrony pokoju (The Defence of Peace Issue is the Life of Namysłów Poviat), "Trybuna Robotnicza”, 20 May 1951.

78 APO, KP PZPR w Głubczycach, sygn. 42/II/1, Sprawozdanie Powiatowego Komitetu Obrońców Pokoju w Głubczycach [1951 r.] (Report from the Poviat Comittee of the Defenders of Peace in Głubczyce) unnumbered pages; 450 tysięcy kart plebiscytowych złożyła już ludność Opolszczyzny (450,000 Plebiscite Cards Already Cast by People of Opole Region), "Dziennik Zachodni”, 20 May 1951; Akcja plebiscytowa zakończona (The Plebiscite Campaign Finished), “Dziennik Zachodni”, 25 May 1951.

79450 tysięcy kart plebiscytowych złożyła już ludność Opolszczyzny (450,000 Plebiscite Cards Already Cast by People of Opole Region), “Dziennik Zachodni”, 20 May 1951; Pierwszy dzień Narodowego Plebiscytu Pokoju na Opolszczyźnie (The First Day of the National Plebiscite for Peace in Opole region), "Dziennik Zachodni", 18 May 1951; Plebiscyt Pokoju na Opolszczyźnie manifestacja jedności całego społeczeństwa (The Plebiscite for Peace in Opole Region - Manifestation of Unity of the Whole Society), "Trybuna Robotnicza", 19 May 1951; Rzemieślnicy opolscy stajq w szeregach obrońców pokoju biorqc gremialny udział w Plebiscycie (Opole 
The progress of events was exceptional on 22 May, which marked the end of voting. Artistic events were organised to celebrate the end of the plebiscite. For example, a special programme was presented (very few people attended it) in the State Theatre of Opole. Performances by school artistic groups were also arranged; for example, in the city park in Namysłów. Cards submission officially ended at three pm. After the forms were collected from the whole poviat, they were transported by car from PKOP seats to Opole. Cars were specially decorated with flowers and banners saying: "Completing the Six-Year Plan, we struggle for peace", "World Camp of Peace will prevail", and for example in Namysłów they were adorned with a picture of a peasant with a sickle and a worker carrying a hammer. The moment of transporting cards back to the voivodeship capital became a pretext to organise peace demonstrations in poviat cities. Delegations leaving for Opole were seen off by groups with flags and banners. This took on an especially festive character in Namysłów. Along the whole route of the car transporting cards, delegations of young people and workers were standing and cheering for peace. The car was stopped at the border of each municipality, and decorated with additional flowers. People were chanting "Peace! Peace!" seeing it off. By the evening of 22 May, votes from all poviats had reached WKOP in Opole. The community of Głogówek attached a special letter to PKOP to their cards. Cards from Kluczbork poviat were placed in a special case made from "dark French polished wood with a white dove on a blue cover"80. After being sorted and prepared for further transportation, cards from WKOP in Opole were sent to Warsaw.

Both during the campaign before voting and on the days of collecting cards, certain troublesome issues appeared connected with the course of the plebiscite. The older generation of the local population tried to compare this campaign to the plebiscite of 1921. So they were asking questions as to why there was only one card not two because they wanted to express their opinion "for" but also "against" ${ }^{11}$. A remark was made that appeals for mass participation in the plebiscite were directed at Poles and did not apply to native Silesians who officially did not have Polish citizenship

Craftsmen Stand Together with Defenders of Peace Taking Part in the Plebiscite), "Trybuna Robotnicza", 19 May 1951; Inteligencja pracujqca Opolszczyzny biorqc udział w Plebiscycie walczy o pokój i rozwój kultury (Working Intelligentsia of Opole Region Taking Part in the Plebiscite Fights for Peace and the Development of Culture), "Trybuna Robotnicza”, 19 May 1951; Pierwszy meldunek plebiscytowy z woj. Opolskiego (The First Plebiscite Account from Opole Voivodeship), "Dziennik Zachodni”, 18 May 1951; APO, KP PZPR w Grodkowie, sygn. 43/VI/6, Sprawozdanie opisowe Powiatowego Komitetu z organizacji i przebiegu Narodowego Plebiscytu Pokoju na terenie powiatu grodkowskiego [1951 r.] (Poviat Committee Descriptive report on the organization and running of the National Plebiscite for Peace in the territory of Grodków Poviat [1951]), unnumbered pages; APO, KM PZPR w Opolu, sygn. 50/IV/3, Sprawozdanie z akcji przygotowawczej i przebiegu Ogólnopolskiego Plebiscytu Pokoju w Opolu [1951 r.] (Report on the preparatory campaign and running of the National Plebiscite for Peace in Opole [1951]), cards 73-77.

80 Triumfalna droga kart plebiscytowych (Triumphant Way of Plebiscite Cards), "Trybuna Robotnicza", 24 May 1951; Plebiscyt pokoju zakończony na terenie woj. Opolskiego (The Plebiscite for Peace Finished in the Territory of Opole Voivodeship), "Dziennik Zachodni”, 24 May 1951.

81 APO, KW PZPR w Opolu, sygn. 248, Protokół nr 20/51 z posiedzenia Egzekutywy KW PZPR w Opolu z 18 V 1951 r. (Protocol no. 20/51 from KW PZPR Executive meeting in Opole from 18 May 1951), cards 74-79; AAN, KC PZPR w Warszawie, sygn. 237/VII-234, Sprawozdanie z wyjazdu służbowego do woj. opolskiego z 28 V 1951 r. (Report on the official trip to Opole Voivodeship), card 36. 
but only a temporary certificate ${ }^{82}$. The openness of voting was criticised as well as the voluntary participation, as some people clearly admitted that they had submitted cards in fear of possible harassment if they had not fulfilled this obligation ${ }^{83}$.

There were notes on some cards. Some voters had added their own anti-war slogans. Also slightly longer statements were made: "I did not sign the Stockholm Appeal as I believed hostile propaganda; now I am signing the plebiscite card because I am convinced that only the struggle for peace gives me the chance to live" ${ }^{\prime \prime 4}$. Some courageous individuals expressed their private worries on signed cards. Most often these were remarks on their desire to leave for Germany in order to be reunited with family ${ }^{85}$. In Dzierżoniów, two people wrote the original text in German translation on the reverse of their cards, omitting the phrase "In the name of Polish independence" and put their signature there. On some cards there were annotations that they were signing cards as Germans ${ }^{86}$.

Contrary to the widely popularised message that the National Plebiscite for Peace met with absolute and total social support, voices of community opposition towards the campaign were noticed. The security apparatus was monitoring social sentiments during the plebiscite, observing, among others, the community of former Home Army members or autochthones of anti-Polish and pro-German attitudes. The effects of these activities, however, were analysed only within closed political circles. The authorities admitted that in the course of the plebiscite campaign numerous unfriendly utterances appeared as regards the political system in Poland of that time. "There are also individuals who indeed do not want war but they would desire a different peace, that is in a different system" ${ }^{17}$. Communities that generated an unfriendly climate

82 Archiwum Instytutu Pamięci Narodowej oddział we Wrocławiu (Archives of the Institute of National Remembrance, department in Wrocław; further: AIPN Wr), sygn. 07/328, vol. 1, card 288, Szef PUBP w Koźlu do Szefa WUBP w Opolu z 5 VI 1951 r. (PUBP manager in Koźle to WUBP manager in Opole), p. 3. Documents form AIPN Wr collections were used thanks to the kindness and advice given by Dariusz Misiejuk, for which I am truly grateful.

83 Ibidem, sygn. 07/67, card 26, PUBP in Głubczyce to WUBP manager in Opole from 6 June 1951, p. 2.

84 AAN, KC PZPR w Warszawie, sygn. 237/VII-234, Sprawozdanie z wyjazdu służbowego do woj. opolskiego z 28 V 1951 r. (Report on an official trip to Opole Voivodeship from 28 May 1951), card 41.

85 APO, KW PZPR w Opolu, sygn. 248, Protokół nr 21/51 z posiedzenia Egzekutywy KW PZPR w Opolu z 25 V 1951 r. (Protocol no. 21/51 from KW PZPR Executive meeting in Opole from 25 May 1951), card 89; APO, KP PZPR w Raciborzu, sygn. 53/II/1, Protokół z posiedzenia plenum KP PZPR w Raciborzu z 22 V 1951 r. (Minutes from KP PZPR plenum meeting in Racibórz from 22 May 1951), unnumbered pages; APO, KP PZPR w Oleśnie, sygn. 49/IV/5, Protokół z posiedzenia egzekutywy KP PZPR w Oleśnie z 22 V 1951 r. (Minutes from KP PZPR Executive meeting in Olesno from 22 May 1951), unnumbered pages; Wielkie dni Plebiscytu Pokoju na Opolszczyźnie (Great Days of the Plebiscite for Peace in Opole Region), "Trybuna Robotnicza", 20 May 1951.

86 APO, KP PZPR w Kluczborku, sygn. 44/V/3, Protokół z odprawy aktywu partyjnego z $22 \mathrm{~V} 1951 \mathrm{r}$. (Minutes from party activists briefing from 22 May 1951), card 4; ibidem, sygn. 44/VI/4, Meldunek z posiedzenia aktywu KP PZPR Kluczbork z 22 V 1951 r. (Kluczbork KP PZPR activists account from 22 May 1951).

87 APO, KP PZPR w Raciborzu, sygn. 53/II/1, Protokół z posiedzenia plenum KP PZPR w Raciborzu z 14 V 1951 r. (Minutes from KP PZPR plenum meeting in Racibórz from 14 May 1951), unnumbered pages. APO, WKOP, sygn. 1, Sprawozdanie z działalności politycznej i organizacyjnej Woj. Komitetu Obrońców Pokoju w Opolu i terenowych Komitetów Obrońców Pokoju za 1951 r. (Report on political and organisational activity of the Voivodeship Committee of the Defenders of Peace for the year 1951), unnumbered pages. 
were associated with rich farmers, kulaks, who in the opinion of authorities counted on a change of system as a result of a potential war, that is the return of capitalism. Among recorded hostile statements, there were also those that implicated that the Polish authorities "were the first who wanted war because they oppressed people with taxes and did not give them either homes or bread". Another example of "deliberate and refined proceedings of an enemy among people of work" came from Namysłów, where it was stated that campaigns such as the National Plebiscite for Peace would not soften social sentiments and people would rebel against the authorities if there were leaders who would direct them ${ }^{88}$. At a gromada meeting in Królowa in Głubczyce poviat, one of those gathered there suggested a change in the plebiscite content: "So that everybody would sign it with the objective of the Soviet Union giving us back our eastern territories" ${ }^{89}$. Some doubted the effectiveness of the plebiscite as "war is going to happen no matter what", and Western Germany was determined to retake lands lost after the Second World War ${ }^{90}$. Sporadically, antiplebiscite slogans appeared, for example: "Viva America", "War is going to happen regardless", "We are struggling for peace with empty stomachs" ${ }^{91}$. Writing and leaflets in German language questioning voting appeared among others in Radawie and Kalinowice ${ }^{92}$. In Paczków, KOP received an anonymous letter calling for war, signed by Guerilla Squad no. $33^{93}$. On the wall of one of the factories in Brzeg, the following writing appeared: "The Plebiscite is the last resort for the USSR" ${ }^{4}$. Leaflets persuading people to boycott the plebiscite were found in the building of Opole Voivodeship

88 APO, KW PZPR w Opolu, sygn. 1733, Ocena kampanii Narodowego Plebiscytu Pokoju przez Egzekutywę KW PZPR Opole [25 V 1951 r.] (Evaluation of the National Plebiscite for Peace campaign by Opole KW PZPR Executive [25 May 1951]), cards 124-125.

89 AIPN Wr, sygn. 07/67, card 26, PUBP in Głubczyce to WUBP Manager in Opole from 6 June 1951 r., p. 2.

90 APO, KP PZPR w Koźlu, sygn. 45/VIII/1, Protokół z odprawy kierowników Grup Agitatorów z powiatu kozielskiego z 11 V 1951 r. (Minutes from Agitators Groups' managers briefing from Koźle Poviat, dated 11 May 1951), unnumbered pages; AIPN Wr, sygn. 07/370, k. 67, Szef PUBP w Brzegu do Naczelnika Wydziału III WUBP w Opolu z 29 V 1951 r. (Brzeg PUBP Manager to WUBP Third Department Head Manager in Opole from 29 May 1951), p. 3; ibidem, card 123, Szef PUBP w Brzegu do Naczelnika Wydziału III WUBP w Opolu z 30 V 1951 r. (Brzeg PUBP Manager to WUBP Third Department Head Manager in Opole from 30 May 1951), p. 1; ibidem, sygn. 07/328, vol. 1, card 288, Szef PUBP w Koźlu do Szefa WUBP w Opolu z 5 VI 1951 r. (Koźle PUBP Manager to WUBP Manager in Opole from 5 June 1951), p. 3; ibidem, sygn. 07/446, vol. 1, card 30, Szef PUBP w Nysie do Szefa WUBP w Opolu z 4 VI 1951 r. (Nysa PUBP Manager to WUBP Manager in Opole from 4 June 1951), p. 3.

91 APO, KW PZPR w Opolu, sygn. 248, Protokół nr 21/51 z posiedzenia Egzekutywy KW PZPR w Opolu z 25 V 1951 r. (Protocol no. 21/51 from Opole KW PZPR Executive meeting from 25 May 1951), card 89; AIPN Wr, sygn. 07/45, card 30, Szef PUBP w Strzelcach Opolskich do Szefa WUBP w Opolu z 4 VI 1951 r. (Strzelce Opolskie PUBP Manager to WUBP Manager in Opole from 4 June 1951), p. 2.

92 AIPN Wr, sygn. 07/469, vol. 1, PUBP w Oleśnie do Szefa WUBP w Opolu z 4 VI 1951 r. (PUBP in Olesno to WUBP Manager in Opole from 4 June 1951); ibidem, ref.no. 07/45, card 30, Szef PUBP w Strzelcach Opolskich do Szefa WUBP w Opolu z 4 VI 1951 r. (Strzelce Opolskie PUBP Manager to WUBP Manager in Opole from 4 June 1951), p. 2

93 Ibidem, sygn. 07/446, vol. 1, card 31, Szef PUBP w Nysie do Szefa WUBP w Opolu z 4 VI 1951 r. (Nysa PUBP Manager to WUBP Manager in Opole from 4 June 1951), p. 4.

94 APO, KW PZPR w Opolu, sygn. 248, Protokół nr 20/51 z posiedzenia Egzekutywy KW PZPR w Opolu z 18 V 1951 r. (Protocol no. 20/51 from KW PZPR Executive meeting in Opole from 18 May 1951), cards $74-79$. 
National Council and in plants in Zdzieszowice ${ }^{95}$. Plebiscite posters were also occasionally torn down ${ }^{96}$. Some Opole Voivodeship inhabitants were said to have encouraged others to sabotage voting; apparently those who were applying for permission for permanent stay in Germany. These events were of incidental character, and did not escalate any further - according to security apparatus reports and peace and party committees' accounts. In the face of occasional but still noted manifestations of hostility, the Office of Public Security warned people not to "revel in accomplishments" and recommended increased vigilance so that nothing disturbed the proper running of the plebiscite ${ }^{97}$. Communities and individuals that spoke against voting were surrounded by a network of agents and informers sent by the security apparatus ${ }^{98}$.

The National Plebiscite for Peace was accompanied by different rumours, distorting its sense and aimed at discouraging people from participation. In Opole Voivodeship there was a widespread speculation that the plebiscite was voting for the transformation of Poland into another republic of the USSR ${ }^{99}$. Initialling a card was to express one's acceptance of the Six-Year Plan or access to a production cooperative. It was feared that signing the Berlin Appeal would result in deportation deep into the USSR or prevention from access to Germany for persons who had been applying for departure. It was said that only persons under sixty were allowed to take part in the plebiscite as older people who voted would be deprived of their pensions and retirement money. People were also threatened that participation in the plebiscite would result in their exclusion from the Church ${ }^{100}$.

95 Ibidem, Protokół z posiedzenia Egzekutywy KW PZPR w Opolu z 11 V 1951 r. (Minutes from KW PZPR Executive meeting in Opole from 11 May 1951), card 44; AIPN Wr, sygn. 07/45, card 33, Szef PUBP w Strzelcach Opolskich do Szefa WUBP w Opolu z 4 VI 1951 r. (Strzelce Opolskie PUBP Manager to WUBP Manager in Opole from 4 June 1951), p. 5.

96 APO, KM PZPR w Opolu, sygn. 50/IV/4, Ocena sytuacji politycznej na terenie miasta Opola w m-cu maju $1951 \mathrm{r}$. (Evaluation of political situation in the territory of Opole city in May 1951), card 430.

97 APO, KP PZPR w Raciborzu, sygn. 53/II/1, Protokół z posiedzenia plenum KP PZPR w Raciborzu z 14 V 1951 r. (Minutes from KP PZPR plenum meeting in Racibórz from 14 May 1951), unnumbered pages.

98 For example: AIPN Wr, sygn. 07/67, card 26, PUBP w Głubczycach do Szefa WUBP w Opolu z 6 VI 1951 r (PUBP in Głubczyce to WUBP Manager in Opole from 6 June 1951), p. 2; ibidem, sygn. 07/328, vol. 1, card 288, Szef PUBP w Koźlu do Szefa WUBP w Opolu z 5 VI 1951 r. (Koźle PUBP Manager to WUBP Manager in Opole from 5 June 1951), p. 3; ibidem, sygn. 07/469, vol. 1, PUBP w Oleśnie do Szefa WUBP w Opolu z 4 VI 1951 r. (PUBP in Olesno. to WUBP Manager in Opole from 4 June 1951); ibidem, sygn. 07/370, card 149, Raport okresowy Kier. Referatu V-go za okres od dnia 30 IV do dnia 31 V 1951 r. (Periodic report by the Fifth Department Manager for the period from 30 April until 21 May 1951); ibidem, sygn. 07/45, card 30, Szef PUBP w Strzelcach Opolskich do Szefa WUBP w Opolu z 4 VI 1951 r. (Strzelce Opolskie PUBP Manager to WUBP Manager in Opole from 4 June 1951), p. 2.

99 AIPN Wr, sygn. 07/67, card 26, PUBP w Głubczycach do Szefa WUBP w Opolu z 6 VI 1951 r. (PUBP in Głubczyce to WUBP Manager in Opole from 6 June 1951), p. 2.

100 AAN, KC PZPR w Warszawie, sygn. 237/VII-1830, Informacja o działalności wroga z $17 \mathrm{~V} 1951 \mathrm{r}$. (Information on the enemy's activity from 17 May 1951), card 201; APO, KW PZPR w Opolu, sygn. 2497, Sprawozdanie z przebiegu zebrania agitatorów gminy Popielów pow. Opole dotyczące Narodowego Plebiscytu Pokoju z 7 V 1951 r. (Report on the running of agitators' meeting in Popielów Municipality, Opole Poviat as regards the National Plebiscite for Peace from 7 May 1951), card 4; APO, KP PZPR w Raciborzu, sygn. 53/II/1, Protokół z posiedzenia plenum KP PZPR w Raciborzu z 14 V 1951 r. (Minutes from KP PZPR plenum meeting in Racibórz from 14 May 1951), unnumbered pages.; ibidem, sygn. 53/II/1, Sprawozdanie przebiegu plebiscytu narodowego na terenie Raciborza (Report on the National Plebiscite running in the territory of Racibórz), unnumbered pages; Gmina Pokój walczy o pokój (Pokój Municipality fights for peace), "Trybuna Robotnicza", 20 May 1951. 
After all the votes were counted, it turned out that the frequency in the plebiscite had been very high and was over 99 per cent in Opole Voivodeship (table 1). This result did not differ from those achieved in other regions of the country. In Opole Voivodeship, cards were not submitted most of all by people who were staying outside its territory, for example on holidays or delegations. 0.13 per cent of those qualified to vote refused to participate in the event ${ }^{101}$.

Table 1. Results of the National Plebiscite for Peace for respective poviats of Opole Voivodeship.

\begin{tabular}{|c|c|c|c|c|c|}
\hline Poviat & $\begin{array}{l}\text { Number of qualified } \\
\text { to vote }\end{array}$ & Number of votes cast & $\%$ & $\begin{array}{l}\text { How many } \\
\text { refused }\end{array}$ & $\begin{array}{l}\text { How many } \\
\text { were absent }\end{array}$ \\
\hline Opole City Com. & 38,899 & 38,162 & 98 & 23 & 714 \\
\hline Brzeg Poviat Com. & 28,049 & 27,788 & 99 & 25 & 236 \\
\hline Głubczyce Poviat Com. & 35,062 & 34,994 & 99.8 & 12 & 56 \\
\hline Grodków Poviat Com. & 19,032 & 19,026 & 99.9 & 6 & $x$ \\
\hline Kluczbork Poviat Com. & 30,506 & 30,481 & 99.9 & 25 & $x$ \\
\hline Koźle Poviat Com. & 55,501 & 55,336 & 99.7 & 10 & 155 \\
\hline Namystów Poviat Com. & 17,115 & 17,104 & 99.9 & 11 & $\mathrm{X}$ \\
\hline Niemodlin Poviat Com. & 20,160 & 19,739 & 98 & 65 & 351 \\
\hline Nysa Poviat Com. & 49,342 & 49,134 & 99.6 & 20 & 188 \\
\hline Olesno Poviat Com. & 32,914 & 32,776 & 99.6 & 138 & $x$ \\
\hline Opole Poviat Com. & 80,730 & 80,315 & 99.5 & 314 & 101 \\
\hline Prudnik Poviat Com. & 53,735 & 53,642 & 99.8 & 48 & 45 \\
\hline Racibórz Poviat Com. & 57,104 & 57,073 & 99.9 & 31 & $\mathrm{x}$ \\
\hline Strzelce Poviat Com. & 58,756 & 58,727 & 99.9 & 23 & 6 \\
\hline In total & 576,905 & 574,297 & 99.5 & 751 & 1857 \\
\hline
\end{tabular}

Source: APO, KW PZZPR w Opolu, sygn. 1733, Letter of KW PZPR in Opole from 23 May 1951, card 117. 
The largest number of refusals was noted in Opole Poviat, then in Olesno and Niemodlin Poviats. More often, the plebiscite was ignored by people who were to vote in the place of their living (75 per cent) than those who were to submit cards at their places of work. Most of all, inhabitants of villages resigned from taking part in the action too (83 per cent). Slightly over a half of all persons who had refused to submit cards were farmers. According to official results, all priests participated in voting. Detailed data on the matter are presented in table 2.

Table 2. Results of the National Plebiscite for Peace in Opole Voivodeship according to data from 25 May 1951.

\begin{tabular}{|c|c|c|c|}
\hline & Qualified for voting & Signed cards & Refused to sign \\
\hline In total & 576,980 & 574,372 & 751 \\
\hline Men & 267,147 & 265,446 & 338 \\
\hline Women & 309,833 & 308,926 & 413 \\
\hline In cities & 189,905 & 188,765 & 126 \\
\hline In villages & 387,075 & 385,607 & 112 \\
\hline In production plants & 145,538 & 144,851 & 38 \\
\hline In institutions and offices & 22,392 & 22,780 & 41 \\
\hline At schools and universities & 54,423 & 54,385 & 560 \\
\hline At place of residence & 354,207 & 226,708 & 417 \\
\hline Peasants & 227,207 & 226,708 & X \\
\hline Priests & 492 & 492 & \\
\hline
\end{tabular}

Source: APO, KW PZZPR w Opolu, sygn. 1733, Letter of KW PZPR in Opole from 25 May 1951, card 118.

Among the 751 persons who refused to submit cards, a great part were Jehovah's Witnesses. They explained their distance toward the campaign on the basis of their religious commands - from their point of view peace in the world depended most of all on God. Some of them, acting under pressure from agitators, signed cards and made annotations that they were supporting "the peace of God"102. Party authorities

102 AAN, KC PZPR w Warszawie, sygn. 237/VII-234, card 41, Sprawozdanie z wyjazdu służbowego do woj. opolskiego z 28 V 1951 r. (Report on an official trip to Opole Voivodeship on 28 May 1951), card 41; ibidem, sygn. 237/VII-1696, Wewnętrzny Biuletyn Informacyjny Referatu Sprawozdawczego KW PZPR 
considered Jehovah's Witnesses a subversive group cooperating with the West. One Opole KM PZPR member, whose wife belonged to this religious denomination, argued that there was a special agitation conducted among them against the plebiscite and that "American imperialism agents" had contacted them ${ }^{103}$.

Equally numerous refusals to participate in the plebiscite came from autochthones. These cases were especially widely discussed at Party meetings. Talking with agitators, some autochthones expressed their distance toward the campaign, saying that the plebiscite was directed at Poles, and they were Silesians so it did not refer to them ${ }^{104}$. The statement made by a woman inhabitant of Opole is characteristic in this matter. She said to the commission, giving back her unsigned card: "I will not support Bolshevism, and besides the western borders have not been established yet, and I am not Polish"105. Persons who declared themselves Germans refused to participate in the plebiscite, or those having close family in Germany, and most of all those people who had applied for departure to one of the German states for a substantial amount of time. Inhabitants of Golczowice, a locality situated near the Odra river in Niemodlin Poviat, refused to take part in the plebiscite in the most decisive way. From the beginning of the campaign, they boycotted it - no one came to the meeting with agitators, apart from the village leader and KOP members. In the view of Golczowice inhabitants, the plebiscite had been organized to impose the border at Odra and Nysa Łużycka on Germans. They refused to sign cards for fear

w Opolu z 14 V 1951 r. (Internal News Bulletin of KW PZPR Reporting Department in Opole from 14 May 1951); APO, KW PZPR w Opolu, sygn. 1733, Zestawienie osób, które odmówiły podpisu pod apelem pokoju z 17 V 1951 r. (do godz. 22.00) (List of persons who refused to sign the peace appeal from 17 May 1951 (until 10 pm), card. 81; ibidem, sygn. 248, Protokół z posiedzenia Egzekutywy KW PZPR w Opolu z 18 V 1951 r. (Minutes from KW PZPR Executive meeting in Opole from 18 May 1951), cards 74-79; APO, KP PZPR w Grodkowie, sygn. 43/VI/6, Sprawozdanie opisowe Powiatowego Komitetu z organizacji i przebiegu Narodowego Plebiscytu Pokoju na terenie powiatu grodkowskiego [1951 r.] (Descriptive report of Poviat Committee on the organisation and running of the National Plebiscite for Peace in the territory of Grodków Poviat), unnumbered pages; APO, KM PZPR w Opolu, sygn. 50/IV/3, Protokół z posiedzenia Egzekutywy KM PZPR w Opolu z 28 V 1951 r. (Minutes from KM PZPR Executive meeting in Opole from 28 May 1951), card 148. If Party members were among Jehovah's Witnesses refusing to take part in the plebiscite, they were excluded from PZPR. APO, KP PZPR w Oleśnie, sygn. 49/IV/5, Protokół z posiedzenia egzekutywy KP PZPR w Oleśnie z 22 V 1951 r. (Minutes from KP PZPR Executive meeting in Olesno from 22 May 1951), unnumbered pages.

103 APO, KM PZPR w Opolu, sygn. 50/IV/3, Protokół z poszerzonego posiedzenia Egzekutywy KM PZPR w Opolu z 22 V 1951 r. (Minutes from KM PZPR Executive extended meeting in Opole from 22 May 1951), cards 239-245.

104 APO, KW PZPR w Opolu, sygn. 1733, Ocena kampanii Narodowego Plebiscytu Pokoju przez Egzekutywę KW PZPR Opole [25 V 1951 r.] (Evaluation of the National Plebiscite for Peace campaign by Opole KW PZPR Executive [25 May 1951]), card 124; APO, Niemodlin KP PZPR, sygn. 47/I/1, Sprawozdanie z działalności KP PZPR w Niemodlinie za okres 15 XII 1951 - 3 I 1953 r. (Report on KP PZPR activity in Niemodlin for period 15 December 1951 - 3 January 1953), p. 11; ibidem, Uchwała III konferencji powiatowej PZPR w Niemodlinie z 2 XII 1951 r. (Resolution of the Third PZPR Poviat Conference in Niemodlin from 2 December 1951), p. 1; ibidem, Protokół z IV konferencji powiatowej PZPR w Niemodlinie z 17-18 I 1953 r. (Protocol from the Fourth PZPR Poviat Conference in Niemodlin from 17-18 January 1953), p. 6; AAN, KC PZPR w Warszawie, sygn. 237/VII-1678, Meldunek sytuacyjny w związku z Plebiscytem Pokoju na terenie województwa opolskiego z 17 V 1951 r. (Situational report in connection with the Plebiscite for Peace in the territory of Opole Voivodeship from 17 May 1951), card 41.

105 AAN, KC PZPR w Warszawie, sygn. 237/VII-1678, Meldunek Referatu sprawozdawczego KW PZPR w Opolu do KC PZPR w Warszawie z 18 V 1951 r. (Account of KW PZPR Reporting Department in Opole to KC PZPR in Warsaw from 18 May 1951), card 42. 
of "being made Poles then". On the second day of the plebiscite, the chairman of the Municipal National Council in Skorogoszcz forbid the sale of items in GS store ${ }^{106}$ to those of Golczowice's inhabitants who had not submitted their cards yet. PZPR Poviat Committee intervened in this issue, and sent an additional group of agitators to the village, who finally persuaded part of the inhabitants to participate in the plebiscite ${ }^{107}$. Strong resistance of autochthones toward the plebiscite was also observed in such municipalities as Popielów, Dąbrówka Górna, Pokój and Zagwiździe and in some gromady in Olesno poviat ${ }^{108}$. With regard to these attitudes, plebiscite cards in German were prepared that were expected to be signed by all those people ${ }^{109}$.

In some localities, groups of inhabitants refusing to take part in the plebiscite pointed out problems they were facing. In Tułowice, people collectively declared they would not submit cards in response to excesses and maladministration by a local Citizen's Militia official. In this case, analogically to Golczowice, the reaction of Party authorities and additional agitation work were necessary ${ }^{110}$. Refusals to submit plebiscite cards were also an expression of disapproval of fiscal pressure and high compulsory delivery requirements. So, for example, "because of rigorous collecting of crops in gromada", 33 inhabitants of Olesno refused to submit cards ${ }^{111}$. Individuals refused for their own reasons, personal grievances towards authorities or frustrations, for example because of loss of work, religious beliefs ("I cannot serve two masters, I serve only one God"), difficult material conditions ("Give me bread not paper"). Reports reveal that certain people at the margins of society who did not take part in the plebiscite were deaf and dumb, blind or mentally ill persons ${ }^{112}$.

106 GS store - GS stands for Gminna Spółdzielnia, that is Municipal Cooperative (translator's note).

107 Ibidem, sygn. 237/VII-234, Sprawozdanie z wyjazdu służbowego do woj. opolskiego z 28 V 1951 r. (Report on the official trip to Opole Voivodeship from 28 May 1951), card 40.

108 Ibidem, card 39.

109 AAN, KC PZPR w Warszawie, sygn. 237/VII-1696, Wewnętrzny Biuletyn Informacyjny Referatu Sprawozdawczego KW PZPR w Opolu z 22 V 1951 r. (Internal News Bulletin of Kw PZPR Reporting Department in Opole from 22 May 1951)

110 Ibidem, sygn. 237/VII-234, Sprawozdanie z wyjazdu służbowego do woj. opolskiego z $28 \mathrm{~V} 1951 \mathrm{r}$. (Report on official trip to Opole Voivodeship from 28 May 1951), card 40.

111 APO, KP PZPR w Oleśnie, sygn. 49/IV/5, Protokół z posiedzenia egzekutywy KP PZPR w Oleśnie z 22 V 1951 r. (Minutes from KP PZPR Executive meeting in Olesno. from 22 May 1951), unnumbered pages.

112 APO, KP PZPR w Oleśnie, sygn. 49/IV/5, Sprawozdanie z przebiegu akcji plebiscytowej na terenie powiatu oleskiego (Report on the running of the plebiscite action in the territory of Olesno. Poviat), unnumbered pages; ibidem, Protokół z posiedzenia egzekutywy KP PZPR w Oleśnie z 22 V 1951 r. (Minutes from KP PZPR Executive meeting in Olesno from 22 May 1951), unnumbered pages; AAN, KC PZPR w Warszawie, sygn. 237/VII-1678, Meldunek sytuacyjny w związku z Plebiscytem Pokoju na terenie województwa opolskiego z 17 V $1951 \mathrm{r}$. (Situational account in connection with the Plebiscite for Peace in the territory of Opole Voivodeship from 17 May 1951), card 41; APO, KW PZPR w Opolu, sygn. 1733, Zestawienie osób, które odmówiły podpisu pod apelem pokoju z $17 \mathrm{~V} 1951 \mathrm{r}$. (do godz. 22.00) (List of persons who refused to sign the peace appeal from 17 May 1951), card 81; APO, KM PZPR w Opolu, sygn. 50/IV/3, Sprawozdanie z akcji przygotowawczej i przebiegu Ogólnopolskiego Plebiscytu Pokoju w Opolu [1951 r.] (Report on the preparatory action and running of the National Plebiscite for Peace in Opole [1951]), cards 73-77. 
In answer to all kinds of negative attitudes to the plebiscite, agitation activities were intensified. KOP representatives would come to those who had refused to submit cards, and repeated their visits until they persuaded the unwilling to vote. According to reports from the campaign, many of those, toward whom reasonable arguments were used and the importance of the plebiscite and the action for peace explained, signed cards "with tears in their eyes". In cases when refusals were caused by discrimination or unjust treatment on the part of the authorities (these were noted mainly in Opole Poviat), agitators tried to solve the problems. This issue may be illustrated by an example from Krogulno, where one woman threw an agitator out of her house, complaining that the state had abandoned her: she had no access to medical care and had been refused a pension. An agitator got a doctor to come and visit her, arranged a place in hospital and medications as well as turned to the Municipal National Council in order to provide financial support for the inhabitant. After this intervention, the woman signed the card ${ }^{113}$.

According to official reports, no compulsion was used during the plebiscite. Party reports reveal that individual cases of abuse took place in this matter. For example, the chairman of the Municipal National Council in Bogacice put pressure on agitators to take part in the campaign ${ }^{114}$. It was also reported that a militia commandant in the municipality of Sternalice, despite the order that the Citizen's Militia should not take part in agitation and plebiscite works, visited gromada by car and monitors the course of polling ${ }^{115}$.

\section{Summary}

The authorities joined the National Plebiscite for Peace with a whole spectrum of tasks and objectives. The campaign was to make society sensitive to the threat of war, and point out methods by means of which peace needed to be maintained. The narrative was aimed at shaping the sense of patriotism and sensitizing the people to the issue of the defence of state sovereignty. The inviolability of borders was emphasised at that time and - which was quite significant in the context of the specifics of Opole Voivodeship - the right of Poland to the Western Territories. According to official channels, the plebiscite was to contribute to developing international solidarity and brotherhood. The campaign was to illustrate the increase in the power to ensure peace of both the East and the West, and reveal weaknesses in the "the imperialist" camp. This campaign was also connected with the hopes for society's

113 APO, KW PZPR w Opolu, sygn. 1816, Sprawozdanie z kontroli powiatu opolskiego po linii Narodowego Plebiscytu jak również szkolenia partyjnego od dnia 12-19 V $1951 \mathrm{r}$. (Report on the control of Opole Poviat in connection with the National Plebiscite as well as party training from 12-19 May 1951), cards 51-52; AAN, KC PZPR w Warszawie, sygn. 237/VII-234, Sprawozdanie z wyjazdu służbowego do woj. opolskiego z 28 V 1951 r. (Report on official trip to Opole Voivodeship from 28 May 1951), cards 39-40.

114 APO, KP PZPR w Oleśnie, sygn. 49/II/1, Protokół z posiedzenia rozszerzonego plenum KP PZPR w Oleśnie z 4 VI 1951 r. (Minutes from KP PZPR extended plenum meeting in Olesno from 4 June 1951), unnumbered pages.

115 APO, KW PZPR w Opolu, sygn. 248, Protokół nr 20/51 z posiedzenia Egzekutywy KW PZPR w Opolu z 18 V 1951 r. (Protocol no. 20/51 from KW PZPR Executive meeting in Opole from 18 May 1951), cards $74-79$. 
relations with the Communist Party, and gaining citizens' acceptance for political, economic and systemic solutions proposed by the authorities, for example the SixYear Plan, establishing production cooperatives, etc. ${ }^{116}$

Certainly, the National Plebiscite for Peace turned out to be a propaganda success for the authorities. In summary reports the campaign received very positive reviews. It came off better than earlier campaigns of this kind, for example assistance activities for Korea or collecting signatures under the Stockholm Appeal ${ }^{117}$. A very high turn-out was achieved - 99.5 per cent of the qualified inhabitants of Opole Voivodeship took part in the plebiscite. The majority of votes, which had not been predetermined, were collected on the two first days, so the intensified propaganda campaign in villages planned for 20 May, Sunday, was not so necessary any longer. In view of the fact that only individuals refused to participate in the plebiscite, it was announced that social unanimity had been achieved. In the campaign's evaluations, the development of field structures of WKOP was also noted as an accomplishment - many new committees were established, mainly in smaller towns, places of work and in villages. The reaching every citizen in terms of agitation was reported to have been another success. Words of appraisal were spoken about the scale of the propaganda activities undertaken and the variety of means and forms employed. Reports of the campaign tried to persuade the public that it had led to a tranquilizing atmosphere in society and showed effective ways of striving for the maintenance of peace $^{118}$.

The authorities used the plebiscite campaign to present their ideological message - political content was cleverly integrated into the campaign for the protection of peace. These activities were designed to gain new followers, intensifying recruitment to PZPR, ZMP or other organisations. The 45,000 agitators mentioned in reports as being engaged in the campaign raised great expectations. It was openly stated that people active in the campaign were "a solid army for permanent political work"119. New resources gained at that time were to ease expansion of propaganda activity in the region and maintain activity achieved during the campaign in those areas of the

116 APO, KW PZPR w Opolu, sygn. 988, Protokół z odprawy sekretarzy i kierowników Wydziałów Propagandy KP[PZPR] w KW [PZPR] w Opolu z 14 IV 1951 r. (Minutes from KP PZPR Propaganda Departments secretaries and managers' briefing in KW PZPR in Opole from 14 April 1951), card 32; ibidem, sygn. 248, Protokół z posiedzenia Egzekutywy KW PZPR w Opolu z 11 V 1951 r. (Minutes from KW PZPR Executive meeting in Opole from 11 May 1951), card 44.

117 For instance, Władysław Szal pointed out that in Racibórz Poviat only a dozen or so people had not taken part in the plebiscite in comparison with 300 people who had not signed the Stockholm Appeal. APO, KP PZPR w Raciborzu, sygn. 53/II/1, Protokół z posiedzenia plenum KP PZPR w Raciborzu z 22 V 1951 r (Minutes from KP PZPR plenum meeting in Racibórz from 22 May 1951), unnumbered pages. See also: APO, KW PZPR w Opolu, sygn. 1733, Ocena kampanii Narodowego Plebiscytu Pokoju przez Egzekutywe KW PZPR Opole [25 V 1951 r.] (Evaluation of the National Plebiscite for Peace by Opole KW PZPR Executive [25 May 1951]), card 129.

118 APO, KW PZPR w Opolu, sygn. 1733, Ocena kampanii Narodowego Plebiscytu Pokoju przez Egzekutywę KW PZPR Opole [25 V 1951 r.] (Evaluation of the National Plebiscite for Peace campaign by Opole KW PZPR Executive [25 May 1951]), card 125.

119 Ibidem, card 126; APO, KM PZPR w Opolu, sygn. 50/IV/3, Protokół z posiedzenia Egzekutywy KM PZPR w Opolu z 28 V 1951 r. (Minutes from KM PZPR Executive meeting in Opole from 28 May 1951), card 148. 
voivodeship, where inhabitants had earlier kept an explicit distance from political issues $^{120}$. Lively discussions over the World Peace Council Appeal were to improve the awareness of Opole inhabitants concerning the matter of the threat of war as well as the country' defence needs. On this occasion, the enemy was clearly indicated - that is, the broadly understood West, identified mainly with the USA; and the USSR was promoted as an ally in the struggle for peace. In this way, attempts were made to create the acceptance of political cooperation between Poland and its eastern neighbour. This task was fairly important in Opole region as its inhabitants, especially autochthones, had an explicit aversion to the Soviet Union. A slanderous campaign toward the USA was also aimed at inspiring animosity toward the direction of changes Americans were giving to the West German state, which was truly essential in Silesia, considering the pro-German sentiments still live there.

It was emphasised in the summary of the campaign that it had become an opportunity to identify society's needs and problems. Complaints lodged during meetings before the plebiscite revealed the scale of malpractice and impropriety, among others, in field Party committees and offices. As the reports asserted, the prudence of agitators and activists had helped to solve some of the submitted problems. KW PZPR in Opole drew conclusions from these situations and at the meeting summarising the campaign recommended that poviat Party committees monitored the situation in their respective areas in the future and reacted to malpractice and impropriety. In the course of the analysis of the atmosphere in the region, it was admitted that in connection with objections toward the plebiscite made by persons applying for departure to Germany, these people should be allowed to leave Poland in order to avoid escalation of stress and tension. The campaign was also treated as another experience in mobilising the masses and working out methods of dealing with hostile attacks. As was noted, opponents were successfully exposed during the campaign and so were their methods of action and the "large scale of [their] perfidy and diversity of methods when it came to lying"121. It was also emphasised that the campaign taken against the plebiscite had not met with any noticeable success.

The activities undertaken during the campaign before the National Plebiscite for Peace did not entirely fulfil the expectations placed upon them. Contrary to the widely proclaimed slogans, previously intended objectives were not realised. The plebiscite campaign did not contribute to the integration of society. Division between autochthones and immigrants continued in the course of this campaign. Differences among social groups were clearly visible - especially distance between representatives of the intelligentsia engaged in the campaign and groups of workers and peasants showing toward the former "certain degree of hostility". On peace committees, intended supra-party cooperation was not achieved. Many KOPs became dominated by PZPR

120 APO, KM PZPR w Opolu, sygn. 50/IV/4, Ocena sytuacji politycznej na terenie miasta Opola w m-cu maju 1951 r. (Evaluation of political situation in the territory of Opole city in May 1951), card 430.

121 APO, KW PZPR w Opolu, sygn. 1733, Ocena kampanii Narodowego Plebiscytu Pokoju przez Egzekutywę KW PZPR Opole [25 V 1951 r.] (Evaluation of the National Plebiscite for Peace campaign by Opole KW PZPR Executive [25 May 1951]), card 129. 
members, who isolated people from outside the Party, prearranged the scope and schedule of works, and considered others "necessary decoration"122. Not all committees were working in an equally intensive way. In some poviats, for example in Olesno poviat, activities were focused on village areas, neglecting activities in cities. Training sessions conducted with peace committee members and agitators very often remained at a low level. In the course of seminars, instructions were simply read out loud. This had its consequences in weak discussions during assemblies and mass meetings. Agitators could not cope with questions being asked or the presented comments. Activists paid little attention to the ideological meaning of the campaing; they acted somewhat mechanically and concentrated on recruiting as many plebiscite participants as possible. During the monitoring of preparations for polling, it turned out that some of the declared meetings had not taken place at all ${ }^{123}$. Many problems were also caused by the pace of preparations. The campaign did not proceed as scheduled. Because training sessions dragged on, too little time was left for individual agitation. The level of campaign conducted by very young people was found to be low. Most of all, they were not able to answer people's questions, for example they made fun of older inhabitants, who sought to draw comparisons between the National Plebiscite for Peace and the one from 1921. The young also ridiculed the religiousness of inhabitants, advising them to hang portraits of Stalin, Bierut or doves of peace instead of crosses and images of the saints. When such incidents occurred, interventions by Party activists were necessary to alleviate these situations by sending older activists to those places ${ }^{124}$. It also turned out that some agitators were not properly selected. Many of them did not undertake their duties. In some

122 Ibidem; AAN, KC PZPR w Warszawie, sygn. 237/VII-234, Notatka z wyjazdu służbowego do woj. opolskiego z 4 V 1951 r. (Note from the official trip to Opole Voivodeship from 4 May 1951), card 17; AAN, KC PZPR w Warszawie, sygn. 237/VII-234, Sprawozdanie z wyjazdu służbowego do woj. opolskiego z 28 V 1951 r. (Report on the official trip to Opole Voivodeship from 28 May 1951), card 36.

123 AAN, KC PZPR w Warszawie, sygn. 237/VII-234, Sprawozdanie z wyjazdu służbowego do woj. opolskiego z 28 V 1951 r. (Report on the official trip to Opole Voivodeship from 28 May 1951), card 41; APO, KW PZPR w Opolu, sygn. 248, Protokół nr 20/51 z posiedzenia Egzekutywy KW PZPR w Opolu z 18 V 1951 r. (Protocol no. 20/51 from KW PZPR Executive meeting in Opole from 18 May 1951), cards 74-79; ibidem, Protokół z posiedzenia Egzekutywy KW PZPR w Opolu z 11 V 1951 r. (Minutes from KW PZPR Executive meeting in Opole from 11 May 1951), card 44; APO, WKOP, sygn. 1, Sprawozdanie z działalności politycznej i organizacyjnej Woj. Komitetu Obrońców Pokoju w Opolu i trenowych Komitetów Obrońców Pokoju za 1951 r. (Report on the political and organisational activity of the Voivodeship Committee of the Defenders of Peace in Opole and field Committees of the Defenders of Peace for the year 1951), unnumbered pages.; APO, KP PZPR w Oleśnie, sygn. 49/IV/5, Informacja KP PZPR w Oleśnie o przebiegu przygotowań do Narodowego Plebiscytu Pokoju na terenie powiatu oleskiego (Information of KP PZPR in Olesno on the course of preparations for the National Plebiscite for Peace in the territory of Olesno Poviat), unnumbered pages, APO, KP PZPR w Grodkowie, sygn. 43/VI/6, Sprawozdanie opisowe Powiatowego Komitetu z organizacji i przebiegu Narodowego Plebiscytu Pokoju na terenie powiatu grodkowskiego [1951 r.] (Descriptive report from Poviat Committee on the organization and running of the National Plebiscite for Peace in the territory of Grodków Poviat [1951]), unnumbered pages, APO, KM PZPR w Opolu, sygn. 50/IV/3, Protokół z posiedzenia Egzekutywy KM PZPR w Opolu z 28 V 1951 r., (Minutes from KM PZPR Executive meeting in Opole from 28 May 1951), card 148; Cała Opolszczyzna dokumentuje swa wole walki o pokój i Plan 6-letni (The entire Opole Region is Documenting its Struggle for Peace and the Six-Year Plan), “Trybuna Robotnicza”, 12 May 1951.

124 APO, KW PZPR w Opolu, sygn. 248, Protokół nr 20/51 z posiedzenia Egzekutywy KW PZPR w Opolu z 18 V 1951 r. (Protocol no. 20/51 from KW PZPR Executive meeting in Opole from 18 May 1951), cards 74-79; AAN, KC PZPR w Warszawie, sygn. 237/VII-234, Sprawozdanie z wyjazdu służbowego do woj. opolskiego z 28 V 1951 r. (Report on the official trip to Opole Voivodeship from 28 May 1951), card. 36. 
localities, teams of agitators had to be changed several times and it was necessary to bring in agitators to some villages from other municipalities. Sometimes agitators refused to take part in the plebiscite or even persuaded their neighbours to boycott the voting. Such situations were noted in Koźle, Strzelce and Olesno Poviats ${ }^{125}$. Contrary to opinions popularised for example in the press, engagement in the plebiscite action was far from universal. Most often only individuals joined the event. The First Secretary of KW PZPR in Opole, Roman Nowak, paid attention to this fact in the campaign summary, saying that officially provided data on the number of agitators were overstated and actually did not exceed 27,000 - that many people had been trained ${ }^{126}$.

Another problem turned out to be the distribution of cards. They did not reach everywhere or were delivered to municipal committees at the last minute, leaving agitators only one day to deliver them to voters. Some inhabitants received multiple forms, for example in the place of living and at their place of work. Agitators inadequately instructed people on the procedure of voting, so part of the cards were cast unsigned, only with a name and a surname written. Among other improprieties, it was noted that in some places cards were distributed by children instead of agitators. There were instances of agitators themselves collecting signed cards and delivering them to polling stations, which was to have been done by voters in person $^{127}$. Another difficulty was connected with the lack of financial resources for the plebiscite decorations so they were often made at people's own expense. Part of the committees quite loosely approached the issue of visual propaganda and in their distant territories presented only a few monothematic slogans. It is worth paying attention to the fact that the main subject of the propaganda campaign, that is the pact between the five world powers, was almost non-existent. Slogans on the broadly understood threat of war and the necessity of peace defence were eagerly used but the significance of this treaty, its future signatories or results were not actually referred to at all.

125 APO, KW PZPR w Opolu, sygn. 248, Protokół nr 21/51 z posiedzenia Egzekutywy KW PZPR w Opolu z 25 V 1951 r (Protocol no. 21/51 from Opole KW PZPR Executive meeting from 25 May 1951), card 89; APO, KM PZPR w Opolu, sygn. 50/IV/3, Protokół z poszerzonego posiedzenia Egzekutywy KM PZPR w Opolu z 22 V 1951 r. (Protocol from KM PZPR Executive extended meeting in Opole from 22 May 1951), cards 239-245; APO, KP PZPR w Olesnie, sygn. 49/IV/5, Sprawozdanie z przebiegu akcji plebiscytowej na terenie powiatu oleskiego (Report on running of the plebiscite action in the territory of Olesno Poviat) unnumbered pages; AAN, KC PZPR w Warszawie, sygn. 237/VII-1678, Meldunek Referatu sprawozdawczego KW PZPR w Opolu do KC PZPR w Warszawie z 18 V 1951 r. (Account of KW PZPR Reporting Department in Opole to KC PZPR in Warsaw from 18 May 1951), card 42; 39 tys. aktywistów...

126 APO, KW PZPR w Opolu, sygn. 248, Protokół nr 20/51 z posiedzenia Egzekutywy KW PZPR w Opolu z 18 V 1951 r (Protocol no. 20/51 from Opole KW PZPR Executive meeting from 18 May 1951), cards 74-79.

127 Ibidem; APO, KP PZPR w Olesnie, sygn. 49/IV/5, Protokół z posiedzenia egzekutywy KP PZPR w Oleśnie z 22 V 1951 r. (Minutes from KP PZPR Executive meeting in Olesno from 22 May 1951), unnumbered pages; ibidem, Sprawozdanie z przebiegu akcji plebiscytowej na terenie powiatu oleskiego (Report on running the plebiscite campaign in the territory of Olesno poviat), unnumbered pages; APO, KM PZPR w Opolu, sygn. 50/IV/3, Protokół z posiedzenia Egzekutywy KM PZPR w Opolu z 15 V 1951 r. (Minutes from Opole KM PZPR Executive meeting from 15 May 1951), cards 172-175; AAN, KC PZPR w Warszawie, sygn. 237/VII-234, Sprawozdanie z wyjazdu służbowego do woj. opolskiego z 28 V 1951 r. (Report on the official trip to Opole Voivodeship from 28 May 1951), card 41. 
The plebiscite campaign with its anti-war slogans became a key that was to open society to the voice of the authorities, the door through which the Party was to gain social approval. The rulers tried to create a common front with citizens, and march in step with them. If this was difficult to achieve in an open appeal for support for systemic changes or the Six-Year Plan, the anti-war campaign was an area where it was easier to arrive at cooperation and agreement between the authorities and society. Who would want war, after all? There were few people who openly admitted they counted on a military conflict. In this connection, the plebiscite result was presented not only as a mass protest against the threat to world peace but as a proof of the unanimous support for the authorities, an expression of acceptance toward political, systemic and economic changes. Votes cast in the plebiscite were to prove that the voivodeship inhabitants, while speaking against war, did not agree to any possible changes to borders but accepted the Polish ruler established in Opole Silesia six years earlier. In this context, popularised opinions of autochthones' representatives, who were speaking appreciatively of People's Poland, gained special power. It is also worth paying attention to the fact that arguments used in the campaign about the revival of the Wehrmacht and Nazi movements in Western Germany, touched the past of this part of the voivodeship inhabitants who had functioned in the Nazi system until 1945. One may wonder about what the attitudes of autochthones, former citizens of the Third Reich, who had relatives and acquaintances in both German states, were to attacks on the FRG during the campaign - the state presented before the plebiscite as the centre of revisionism recovering at the inspiration of Western capitalists, and a country of social oppression. Unfortunately, the materials used in this study do not reveal authentic social reactions to the agitation during the plebiscite. They do not characterize the emotional atmosphere and motifs behind the signatures under the Berlin Appeal. It is hard to assess the scale of behaviour showing a lack of approval for the plebiscite and unequivocally state if they were influential. Most of all, there are no accounts of people remembering these events. The few materials documenting the activities of the security apparatus in that period do not indicate a different course of events. One cannot exclude the possibility, though, that a more detailed search using the resources of the Institute of National Remembrance would alleviate these concerns.

The whole enormous organisational effort expended during the National Plebiscite for Peace did not turn out to be fruitful because the peace treaty sought after was not signed anyway. Although the war people were threatened with did not break out, social appeals were not a prevailing argument in this issue. The achieved sense of unanimity between the authorities and different social groups turned out to be short-term, and enthusiasm created at the time of voting and activity of both peace committees and agitators soon petered out ${ }^{128}$. The pace of eager involvement in activities was not hampered though. Right after the announcement of the plebiscite results, society was subjected to a new propaganda campaign - a general subscription for a National Loan for the Development of Poland's Forces.

128 APO, WKOP, sygn. 1, Sprawozdanie z działalności politycznej i organizacyjnej Woj. Komitetu Obrońców Pokoju w Opolu i terenowych Komitetów Obrońców Pokoju za 1951 r. (Report on political and organisational activity of the Voivodeship Committee of the Defenders of Peace in Opole and field Committees of the Defenders of Peace for the year 1951), unnumbered pages. 


\section{Bibliography}

Bałłaban J., Młodzieżowe Warty Pokoju w Zakładach Przemysłu Dziewiarskiego w Głuchołazach, “Dziennik Zachodni”, 17 May 1951.

Kamiński J., Zadanie, które zostanie wykonane na piq̨tkę, “Trybuna Robotnicza”, 20 May 1951.

Kaniak W., Ksiqdz - patriota, “Trybuna Robotnicza”, 21 May 1951.

Leksykon pokoju, ed. by J. Kukułka [et al.], Warszawa 1987.

Osmańczyk E., Cztery przyczyny, “Dziennik Zachodni”, 14 May 1951.

Ostrowski S., Manifestacyjny przebieg Plebiscytu w powiecie kozielskim, "Trybuna Robotnicza”, 22 May 1951.

Pocałun Z., Wielki dzień Paczkowa, “Trybuna Robotnicza”, 22 May 1951.

Ślusarczyk J., Ruch obrońców pokoju w latach 1948-1989. Kompendium, Warszawa 1996. 


\section{Organization and Running of the National Plebiscite for Peace in Opole Voivodeship}

Abstract: The National Plebiscite for Peace took place in Poland between 17 and 22 May 1951 under the auspices of the Polish Committee of the Defenders of Peace. The campaign aimed to gather signatures under the Berlin Appeal announced by the World Peace Council as regards signing the Peace Treaty between five world powers. Voting was preceded by an intensive propaganda campaign in defence of peace and condemning "warmongers". In Opole Voivodeship, analogically to the whole country, numerous peace committees came into existence before the plebiscite. A group of about 40,000 activists were recruited. Many gatherings, mass meetings and demonstrations were organized. Propaganda was conducted by means of press, film, radio and radio systems. To celebrate the plebiscite, production commitments were undertaken and special decorations prepared. In Opole Voivodeship 99.5 per cent of people qualified for voting submitted cards with signatures as part of the Appeal of the World Peace Council. The few refusals came mainly from Jehovah's Witnesses and native inhabitants who declared themselves Germans or applied for departure and permanent stay in Germany. The campaign's objective was to indicate sources of threats of war and methods for the maintenance of peace. Moreover, the campaign was to cause an increase in social acceptance of the authorities and the programme of political and economic changes being implemented by the government. The results of these efforts turned out to be temporary.

Keywords: Peace Defenders Movement, National Plebiscite for Peace, Opole Voivodeship, Upper Silesia, peace appeal, Committee of the Defenders of Peace, Berlin Appeal, Stalinism, World Peace Council, communist propaganda 